\title{
Respiration and sequestering of organic carbon in shelf sediments of the oligotrophic northern Aegean Sea
}

\author{
H. Ståhl' ${ }^{1}$, P. O. J. Hall ${ }^{1, *}$, A. Tengberg ${ }^{1}$, A. B. Josefson ${ }^{2}$, N. Streftaris ${ }^{3}$, A. Zenetos ${ }^{3}$, \\ A. P. Karageorgis ${ }^{3}$ \\ ${ }^{1}$ Department of Chemistry, Marine Chemistry, Göteborg University, Kemivägen 10, 41296 Göteborg, Sweden \\ ${ }^{2}$ National Environmental Research Institute, PO Box 359, 4000 Roskilde, Denmark \\ ${ }^{3}$ National Centre for Marine Research, PO Box 712, Mavro Lithari, Anavyssos, 19013 Attiki, Greece
}

\begin{abstract}
Respiration and sequestering of organic carbon was investigated in northern Aegean Sea sediments (NE Mediterranean). Benthic total carbonate $\left(\mathrm{C}_{\mathrm{T}}\right.$, also called $\Sigma \mathrm{CO}_{2}$ or dissolved inorganic carbon, DIC) fluxes and $\mathrm{O}_{2}$ uptake rates were measured in situ using a benthic lander. Dissolved organic carbon (DOC) fluxes were calculated from pore water gradients, taking into account the influence of biodiffusion/bioirrigation. Macrofaunal biomass was determined in the sediment collected by the chambers of the benthic lander. $\mathrm{Chl}$ a distributions were used as a tracer of high-quality sedimentary organic carbon. The measured benthic $\mathrm{C}_{\mathrm{T}}$ fluxes were positively correlated with the $\mathrm{O}_{2}$ uptake rates. The obtained average apparent respiration ratio $\left(\mathrm{C}_{\mathrm{T}}\right.$ flux: $\mathrm{O}_{2}$ flux $)$ of $0.90 \pm 0.36$ suggests a clear dominance of aerobic respiration in these organic carbon-poor shelf sediments. The $\mathrm{C}_{\mathrm{T}}$ efflux, the $\mathrm{O}_{2}$ uptake rate, and the DOC flux were significantly higher in spring than in fall at 2 of the stations. The Black Sea water, which enters the Aegean Sea in the study area, did not influence benthic respiration rates or organic carbon sequestering rates. A strong positive correlation between both the $\mathrm{C}_{\mathrm{T}}$ and $\mathrm{O}_{2}$ fluxes and the mean chl a concentration in surficial sediment suggests that benthic respiration, to a large extent, was controlled by the availability of labile phytodetrital organic matter. There was no influence of macrofaunal biomass (dry weight) on $\mathrm{C}_{\mathrm{T}}$ fluxes or oxygen uptake rates. The calculated benthic DOC fluxes made up 7.2 to $27 \%$ (average $14 \pm 8.1 \%$ ) of the $\mathrm{C}_{\mathrm{T}}$ fluxes, indicating that their contribution to the overall recycling of organic carbon in these sediments was important. The organic carbon burial efficiency ranged from 0.1 to $5.3 \%$, but at Stn KA1 it was considerably higher (average $4 \%$ ) than at the other stations (average $0.3 \%$ ). Except for this station, the obtained burial efficiencies were very low compared to other sediments with similar accumulation rates. The average burial flux of organic carbon corresponded to less than $1 \%$ of the annual mean primary production (PP) for the Aegean Sea at Stn KA1, and to less than $0.1 \%$ of PP at the other stations.
\end{abstract}

KEY WORDS: Northern Aegean Sea · Sediment - Organic carbon · Dissolved inorganic carbon · Dissolved organic carbon · Oxygen $\cdot$ Chlorophyll $\cdot$ Benthic lander

\section{INTRODUCTION}

The ocean system plays an important role in regulating the climate of earth. Continental margins, which comprise less than $10 \%$ of the ocean in area and much less in volume, are the most active sites of biogeochemical processes in the ocean (e.g. Wollast 1991, Liu et al. 2000a). Estimates suggest that 75 to $85 \%$ of all organic carbon undergoing long-term burial in the global ocean is buried in continental margin sediments (Middelburg et al. 1997, Liu et al. 2000a). This sequestering of organic carbon in sediments is believed to control the atmospheric oxygen level on geological time-scales (Berner 1982, Holland 1984, Berner \& Can- 
field 1989). The role of continental margins in the global biogeochemical cycles has received increased attention in recent years. The high input of terrestrial material and increasing human activities in coastal zones make continental margins most susceptible to anthropogenic disturbance (e.g. Liu et al. 2000b).

The northern Aegean Sea is one of the most oligotrophic areas of the eastern Mediterranean, and a recent estimate of annual primary production of ca. $30 \mathrm{~g} \mathrm{C} \mathrm{m}^{-2} \mathrm{yr}^{-1}$ was provided by Ignatiades et al. (2002). The importance of sediments as sites for remineralisation and sequestering of organic carbon in this oligotrophic shelf environment is largely unknown. However, the Aegean Sea, especially its northern part, is presumably an area of great importance since it is the region where the Black Sea water (BSW) enters the Mediterranean through the Dardanelles Strait. The mixing of BSW with the underlying Levantine Intermediate Water (LIW) create thermohaline fronts and related jets nearby the Lemnos Island (Zervakis et al. 2000), where the work of the EU-MAST III project KEYCOP (key coastal processes in the mesotrophic Skagerrak and the oligotrophic North Aegean Sea - a comparative study) has been focused. This study was carried out within the frame of the KEYCOP project.

The aims of the present study were to determine rates of organic carbon respiration and sequestering in sediments of the northern Aegean to provide knowledge on the fate of organic carbon deposited in these sediments. To study the influence of the thermohaline front on benthic respiration rates, investigations were made at several stations on a transect south of, and through, the front. We also studied the influence of benthic macrofaunal biomass and the availability of fresh phytodetritus on organic carbon remineralisation rates, temporal variability of these rates, and whether the flux of dissolved organic carbon was an important component of organic carbon recycling in these sediments. This study contributes to the growing knowledge on the importance of continental margin sediments in the oceanic carbon cycle.

\section{MATERIALS AND METHODS}

Study site. The Aegean Sea is the body of water between Greece and Turkey in the northeastern part of the Mediterranean Sea (Fig. 1). A characteristic feature of the northern Aegean is the low salinity (ca. 28 PSU), low temperature, and highly oxygenated (>5.5 $\mathrm{ml} \mathrm{O}_{2} \mathrm{l}^{-1}$ ) BSW. This water outflows as a shallow plume with a thickness of only ca. $20 \mathrm{~m}$ in the summer (Zervakis et al. 2000). The general circulation in the area is cyclonic, directing the BSW at a northwestern direction between the islands of Lemnos and Imvros, along the northern coast of Lemnos (Fig. 1). It is subsequently bifurcated to the south and north and can be detected in surface waters of the northern and western parts of the Aegean. The wind-driven surface circulation is altered during summer when the prevailing strong, cold and dry northerly winds (Etesians) force BSW to the southwest along the east coast of Lemnos (Zervakis et al.; available at: www.biologi.uio.no/mzk/ keycop/partners/main.htm).

The north eastern Aegean Sea is characterised by a relatively extensive shelf and a series of 3 aligned depressions (down to $1600 \mathrm{~m}$ depth) that constitutes the so-called N. Aegean Trough. The main characteristics of the sea-floor in the area are the deep Lemnos Basin north of the island of Lemnos, and the shallow Lemnos Plateau east of the island. In general, the sea bed at the shelf and the upper slope south east and north east of the island can be categorised according to Sakellariou et al. (2000) as follows: rocky sea bed along the coast lines, terrigenous and/or biogenic sand deposits in the shallow parts, and sandy silt or silt deposits in the upper slope area at depths $>100$ to $120 \mathrm{~m}$. Pockets of fine silt have also been detected in shallow areas.

Five stations in the northern Aegean Sea (KA1, KA2, KA3, KA6 and KA7; Fig. 1) at water depths of 80 to $354 \mathrm{~m}$ were visited during 2 cruises. KA1, KA2 and KA7 were examined during the fall cruise in September/October 1999, and KA1, KA2, KA3 and KA6 were visited during the spring cruise in March/April 2000 (Table 1). Stn KA6 was examined twice during the spring cruise. The frontal area under investigation was detected east and southeast of the island of Lemnos where water masses of distinct

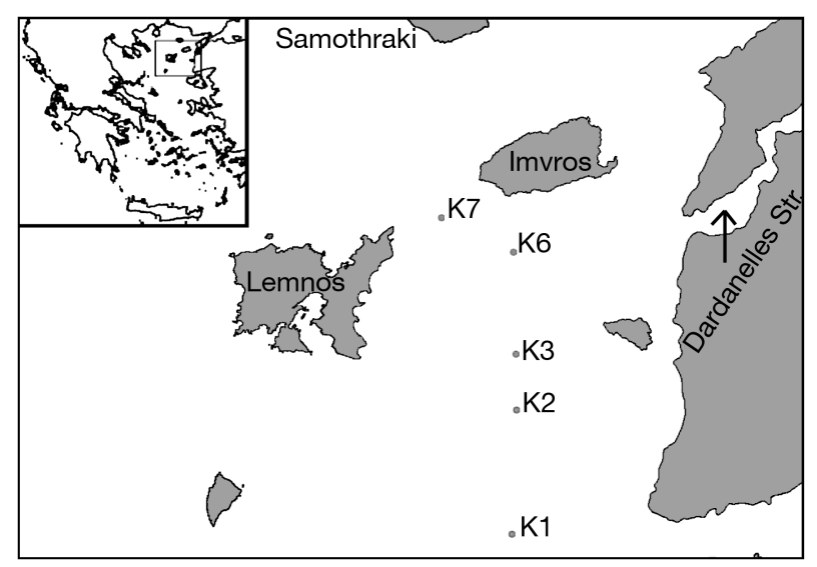

Fig. 1. Map of the Aegean Sea with the different sampling stations indicated. Exact positions of the stations given in Table 1. Investigations (benthic lander deployments, multiple corer sediment sampling) were made at Stns KA1, KA2, KA3, KA6 and KA7. Black Sea water enters the northern Aegean through the Dardanelles Strait 
Table 1. Dates, positions and hydrographic data from all deployments made with the Göteborg benthic lander during the 2 expeditions in the northern Aegean Sea. Sediment sampling with a multiple corer was made at the same stations. $\mathrm{BW} \mathrm{O}_{2}$ : bottom water oxygen concentration; sat.: oxygen saturation. Sediment type and \% sand/mud at the various stations are also given. nm: not measured

\begin{tabular}{|c|c|c|c|c|c|c|c|c|c|}
\hline Stn ID & $\begin{array}{c}\text { Date } \\
\text { (mm/yy) }\end{array}$ & $\begin{array}{l}\text { Latitude } \\
\text { N }\end{array}$ & $\begin{array}{c}\text { Longitude } \\
\text { E }\end{array}$ & $\begin{array}{l}\text { Water } \\
\text { depth } \\
(\mathrm{m})\end{array}$ & $\begin{array}{c}\text { Salinity } \\
\text { (PSU; } \\
\text { surface/bottom) }\end{array}$ & $\begin{array}{c}\text { Temp. }\left({ }^{\circ} \mathrm{C}\right) \\
\text { surface/ } \\
\text { bottom }\end{array}$ & $\begin{array}{c}\mathrm{BW} \mathrm{O}_{2} \\
(\mu \mathrm{M}) \\
(\text { sat \%) }\end{array}$ & $\begin{array}{l}\text { Sediment } \\
\text { type }\end{array}$ & $\begin{array}{c}\text { Grain size } \\
\text { (\% sand/ } \\
\% \text { mud })\end{array}$ \\
\hline KA1 & 09/99 & $34^{\circ} 25.6^{\prime}$ & $25^{\circ} 44.5^{\prime}$ & 354 & $39.3 / 38.8$ & $19.9 / 14.2$ & 219/87 & Mud & $1.0 / 99$ \\
\hline KA7 & $10 / 99$ & $40^{\circ} 07.2^{\prime}$ & $25^{\circ} 30.0^{\prime}$ & 128 & $33.1 / 38.7$ & $22.6 / 16.4$ & $230 / 95$ & Muddy sand & $61 / 39$ \\
\hline KA2 & $10 / 99$ & $39^{\circ} 40.0^{\prime}$ & $25^{\circ} 45.0^{\prime}$ & 123 & $39.0 / 39.0$ & $22.7 / 16.6$ & 226/95 & Muddy sand & $79 / 21$ \\
\hline KA1 & $03-04 / 00$ & $39^{\circ} 25.4^{\prime}$ & $25^{\circ} 44.2^{\prime}$ & 342 & $38.2 / 38.8$ & $14.8 / 13.5$ & $253 / 100$ & Mud & $1.0 / 99$ \\
\hline KA3 & $04 / 00$ & $39^{\circ} 46.3^{\prime}$ & $25^{\circ} 44.0^{\prime}$ & 89 & $35.6 / 38.8$ & $13.9 / 13.6$ & $250 / 99$ & $\mathrm{~nm}$ & $\mathrm{~nm}$ \\
\hline KA6a & $04 / 00$ & $39^{\circ} 58.2^{\prime}$ & $25^{\circ} 45.0^{\prime}$ & 80 & $33.9 / 38.5$ & $12.8 / 14.1$ & $236 / 93$ & Muddy sand & $54 / 46$ \\
\hline KA2 & $04 / 00$ & $39^{\circ} 40.8^{\prime}$ & $25^{\circ} 46.3^{\prime}$ & 122 & $38.2 / 38.9$ & $14.7 / 13.6$ & $250 / 99$ & Muddy sand & $79 / 21$ \\
\hline KA6b & $04 / 00$ & $39^{\circ} 58.2^{\prime}$ & $25^{\circ} 45.0^{\prime}$ & 83 & $29.9 / 38.5$ & $12.7 / 13.9$ & $235 / 93$ & Muddy sand & $54 / 46$ \\
\hline
\end{tabular}

chemical characteristics are mixed; frontal conditions should be met at the transect KA6 to KA1 (mid-term report: KEYCOP 2000; available at www.biologi.uio.no/ mzk/keycop/partners/main.htm). Stns KA2 and KA3, being the most representative frontal stations during both cruises (Karageorgis et al. 2003), exhibited a stratification pattern between the low salinity mesotrophic waters of the Black Sea and the high salinity oligotrophic waters of the Aegean (Zervakis et al.; available at: www.biologi.uio.no/mzk/keycop/ partners/main.htm). KA1, characterised by the absence of BSW, was presumably located outside the front during both cruises. Hence, the water column processes here are determined solely by temperaturedriven stratification and mixing of a single water mass of Levantine water (Karageorgis et al. 2003).

Sediment sampling. Sediment cores, collected with a multiple corer (Barnett et al. 1984), were used to obtain sedimentary distributions of several parameters (see below) as well as pore-water distributions of total carbonate $\left(\mathrm{C}_{\mathrm{T}}\right.$, also called $\Sigma \mathrm{CO}_{2}$ or dissolved inorganic carbon, DIC) and dissolved organic carbon (DOC) from the same sites as the benthic lander was deployed. Only cores (10 cm inner diameter, i.d.) with a seemingly undisturbed surface were used. Cores were sectioned with $0.5 \mathrm{~cm}$ resolution down to $2 \mathrm{~cm}$ depth, followed by $1 \mathrm{~cm}$ resolution down to $6 \mathrm{~cm}$ depth, and finally $2 \mathrm{~cm}$ resolution down to $20 \mathrm{~cm}$ depth. Prior to slicing, the overlying bottom water in each core was carefully siphoned off. Subsamples for sediment organic (sedOC) and inorganic (sedIC) carbon, porosity, dry bulk density and grain size were taken at each depth interval after homogenization of sediment. Sampling for chl a was made in separate sediment cores. A $1 \mathrm{ml}$ sample was taken from each homogenized sediment slice for chl a and immediately frozen (ca. $-20^{\circ} \mathrm{C}$ ) and kept in the dark for at least $24 \mathrm{~h}$. Sediment used to obtain pore water was packed into clean polypropylene centrifuge tubes and centrifuged at $2100 \mathrm{rpm}($ ca. $600 \times g)$ for $30 \mathrm{~min}$. The supernatant was filtered through a $0.45 \mu \mathrm{m}$ pore-size cellulose acetate filter and subsequently sampled for $\mathrm{C}_{\mathrm{T}}$ and DOC. The filter had been rinsed with $60 \mathrm{ml}$ of ultrapure Milli-Q water prior to use to avoid DOC contamination (Hulth et al. 1997, Ståhl et al. 2004b). The DOC samples were stored frozen at $-20^{\circ} \mathrm{C}$ in acid, base and Milli-Q water-cleaned polypropylene vials, whereas the $C_{T}$ samples were analyzed onboard ship within a few hours of centrifugation. Whole sediment cores were stored frozen for later determination of ${ }^{14} \mathrm{C}$ age.

In situ measurements of benthic solute fluxes. Benthic solute fluxes of $\mathrm{O}_{2}, \mathrm{C}_{\mathrm{T}}$ and total alkalinity $\left(\mathrm{A}_{\mathrm{T}}\right)$ were measured in situ using the Göteborg benthic lander (Ståhl et al. 2004a,b) on 5 stations during the 2 cruises in the northern Aegean Sea (Table 1). This free-vehicle lander is equipped with 4 squared incubation chambers, each capable of closing off an area of $400 \mathrm{~cm}^{2}$ of the sea floor. A 'Mississippi-type' paddle wheel stirred the overlying water in the chambers during all incubations at a speed of approximately $60 \mathrm{rpm}$. Detailed information about hydrodynamic conditions and performance of this chamber in comparison with other chambers is given in Tengberg et al. (2004). Bottom water was sampled at the end of the incubation with a Niskin sampler mounted on the lander $\sim 2 \mathrm{~m}$ above bottom, as well as with conductivity temperature depth (CTD)-Rosette casts $\sim 5 \mathrm{~m}$ above bottom. The oxygen concentration in each chamber was continuously measured, at 1 min intervals, with Clarke-type oxygen electrodes from Aanderaa Instruments (www.aanderaa.no). During the incubation, a series of 10 discrete water samples were withdrawn at pre-set times in $60 \mathrm{ml}$ polypropylene syringes from each chamber. Glass ampoules $(20 \mathrm{ml})$, connected to 3 of the $60 \mathrm{ml}$ sampling syringes, were 
used to take samples for oxygen inside the chamber. These samples were used for calibration of the electrodes and as a backup for measuring the oxygen concentration change in the chamber. Each ampoule, filled with Milli-Q water before lander deployment, was flushed twice its volume with water from the chamber before the final sampling.

Assuming a linear concentration change over time, the benthic flux $\left(\mathrm{mmol} \mathrm{m} \mathrm{m}^{-2} \mathrm{~d}^{-1}\right)$ in the chambers was obtained from the slope of the best-fit line (achieved by least square linear regression) of the solute concentration versus time plot, and multiplying this by the overlying water height in the chamber. Each sample taken inside the chamber was replaced, through a diffusion barrier tube $(1.5 \mathrm{~mm}$ i.d. and 400 $\mathrm{mm}$ length), by an equal volume of ambient bottom water. All the values from the chamber were corrected for this 'refill water'. This only resulted in a small ( 3 to $6 \%$ ) correction of the measured fluxes. Incubations lasted between 32 and $48 \mathrm{~h}$ (typically $\sim 40 \mathrm{~h}$ ), and after termination of the flux measurements the incubated sediment was brought to the sea surface, together with the overlying bottom water, in the chambers. This provided the opportunity to determine the precise water volume in each chamber, which is essential for calculating the benthic flux. A video on the lander was used to record features on the sea-floor, lander performance and chamber penetration into the sediment. A Recording Current Meter Model 9 (RCM-9 from Aanderaa Instruments) was placed on top of the lander $\sim 2.2 \mathrm{~m}$ above bottom, and it was used for continuous measurements, at $1 \mathrm{~min}$ intervals, of pressure, conductivity, temperature, and oxygen concentration in the ambient bottom water during deployments (Table 1).

After lander retrieval, the water samples were treated as follows: (1) Winkler reagents were immediately added to the $\mathrm{O}_{2}$ glass ampoule samples and to the bottom water $\mathrm{O}_{2}$ samples from the lander mounted Niskin bottle. (2) Chamber and bottom water samples for $\mathrm{C}_{\mathrm{T}}$ and $\mathrm{A}_{\mathrm{T}}$ were filtered through disposable $0.45 \mu \mathrm{m}$-pore-size cellulose acetate filters prerinsed with $60 \mathrm{ml}$ of ultrapure Milli-Q water. The $\mathrm{C}_{\mathrm{T}}$ samples were stored at in situ temperature for, at most, $24 \mathrm{~h}$ in clean and gas-tight $20 \mathrm{ml}$ glass vials, with no headspace, before analysis on-board ship. The $\mathrm{A}_{T}$ samples were stored refrigerated in clean $20 \mathrm{ml}$ plastic vials until analysis after each cruise.

Macrofauna in chambers. Sediment from 10 chambers of the lander was used for macrofauna determinations. The sediment was sieved through a $0.5 \mathrm{~mm}$ mesh to obtain the general community characteristics of the macrozoobenthos present. To assess the vertical stratification of the community in terms of abundance, biomass and size-frequency distribution, sedi- ment from the lander was sectioned at strata 0 to 2,2 to 6,6 to 10 and $>10 \mathrm{~cm}$ at 2 stations during the March 2000 cruise, and sieved through a $0.5 \mathrm{~mm}$ mesh. In all cases, retained organisms were preserved in $4 \%$ formalin stained with Rose Bengal for further laboratory analyses (sorting, identification to species level, and biomass determination). For biomass (wet weight determination), the individuals of each species were carefully dried on filter paper for ca. 1 min before weighing on a high precision balance. Wet weight was converted to dry weight using the conversion factors given in Josefson \& Rasmussen (2000), i.e. 0.24 for Polychaeta, 0.60 for Mollusca (shells included), 0.26 for Crustacea, 0.25 for Echinodermata and 0.08 for miscellaneous.

Analytical methods. Determination of $\mathrm{C}_{\mathrm{T}}$ in bottom water, flux chamber and porewater samples was performed on-board ship using an automated system based on non-dispersive infrared detection of $\mathrm{CO}_{2}$ with a Licor instrument (Goyet \& Snover 1993, O'Sullivan \& Millero 1998). Prior to detection, all of the dissolved carbonate species in the samples were extracted as $\mathrm{CO}_{2}$ gas by acidification with phosphoric acid, followed by nitrogen stripping. The analytical precision was $0.2 \%$ RSD (relative standard deviation) $(\mathrm{n}=10)$ or better, using a sample loop of $4 \mathrm{ml}$. $\mathrm{A}_{\mathrm{T}}$ was determined using a rapid, high-precision, $1 \mathrm{ml}$ sample volume, potentiometric titration method (Haraldsson et al. 1997). The precision of the alkalinity titration was better than $0.25 \%$ RSD $(n=10)$. Both instruments were calibrated and corrected for drift with certified reference material (CRM) from Dickson Laboratories, Scripps Institute of Oceanography, California. Winkler titration was performed on bottom water and chamber oxygen samples with an analytical precision of $0.5 \%$ RSD $(\mathrm{n}=10)$. DOC was determined using a Shimadzu TOC-5000 total carbon analyzer based on the high-temperature catalytic oxidation (HTCO) technique. Inorganic carbon species were removed from DOC samples by adding 50 $\mu \mathrm{l}$ of high purity $2 \mathrm{M} \mathrm{HCl}$ and purging the sample for 10 min with ultrapure air prior to oxidation. All DOC samples were analyzed at minimum in triplicates with an analytical precision of $3 \% \operatorname{RSD}(n=10)$. The instrument was calibrated and corrected for drift with CRM distributed by Dr. D. Hansell, Bermuda Biological Station for Research. Further discussion about blanks and potential contamination problems associated with the DOC determination is given in Ståhl et al. (2004a).

Sediment solid-phase samples for total sedimentary C (sedTC), sedOC, porosity and dry bulk density were dried at $70^{\circ} \mathrm{C}$ until constant weight (at least $24 \mathrm{~h}$ ). Porosity was calculated from the weight of water loss from a known volume of wet sediment, 


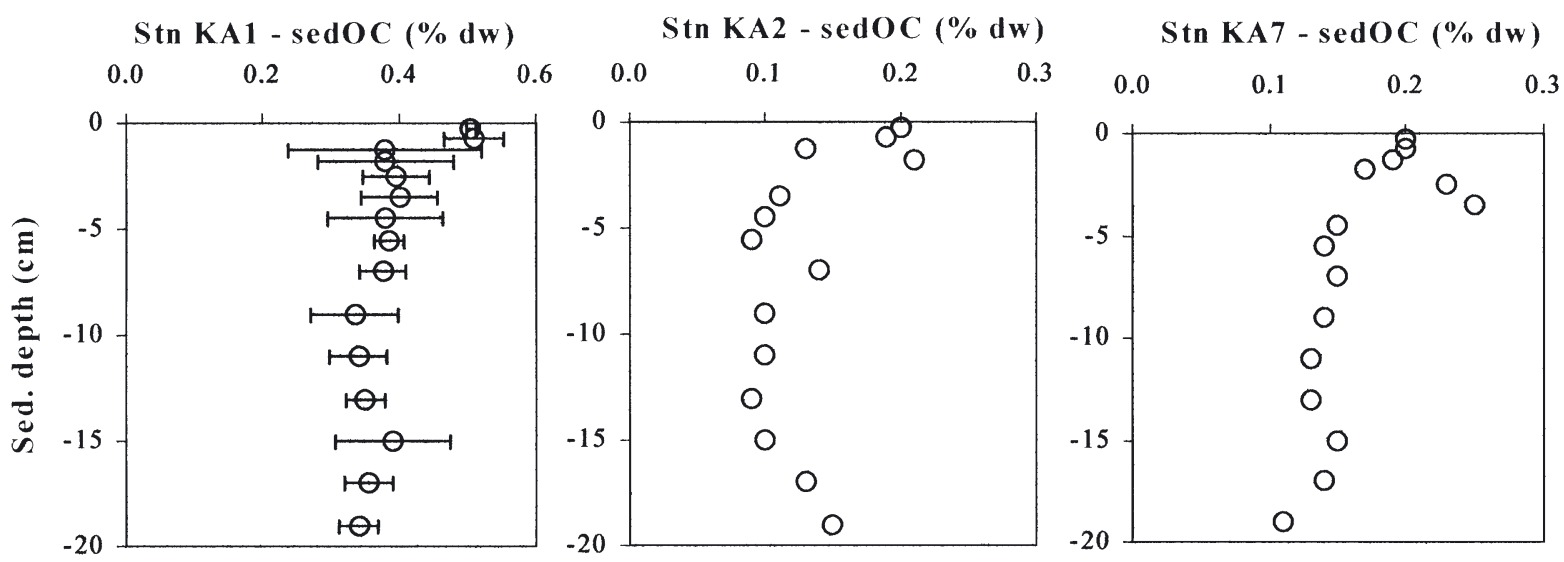

Fig. 2. Profiles of sedimentary organic carbon (sedOC) in \% of sediment dry wt. Error bars denote \pm 1 SD. At each station, 1 to 2 sedOC profiles were measured

and dry bulk density was calculated from the dry weight (dry wt) of a known volume of wet sediment. Samples for sedTC and sedOC were ground into a homogenous powder with an agate mortar and pestle before weighing. For sedOC samples, careful removing of solid phase carbonates was obtained through repeated acid treatment $(2 \mathrm{M} \mathrm{HCl})$ at room temperature until bubbling stopped. Finally, combustion of the sedTC and sedOC samples took place at high temperature $\left(1050^{\circ} \mathrm{C}\right)$ before detection using a Pisons Instrument model $1500 \mathrm{CN}$ CHN analyzer or a Fisons elemental CHN analyzer. SedIC was obtained as the difference between sedTC and sedOC.

For grain size analysis, the sediment was sieved through a $63 \mu \mathrm{m}$ sieve to separate the sandy part, and then treated by a particle size analyzer (Micromeritics SediGraph 5100) for analysis of the finer part. Classification of the substratum was made according to the scheme of Folk (1954).

Chl a samples were thawed and extracted in 96\% ethanol for at least $6 \mathrm{~h}$ in the dark (Jespersen \& Christoffersen 1987). Volume of extraction fluid (10 $\mathrm{ml}$ ) was 10 times the volume of the sediment sample to ensure complete extraction. Extracts were filtered through a Whatman GF/F filter before analysis on a Turner TD 700 fluorometer for chl a using the acid method (Strickland \& Parsons 1972). However, chl a is likely to be overestimated by this method (Falkowski \& Sucher 1981) and a more appropriate term would perhaps be the acid-labile fluorescent fraction at the actual wavelength. Nevertheless, for the sake of simplicity, we use the term chl a throughout the paper.

The ${ }^{14} \mathrm{C}$ method was used for age determination of dried homogenized samples from 14 to $16 \mathrm{~cm}$ depth in sediment cores. Visible shells were first removed from the samples. The inorganic carbon fraction was then extracted with phosphoric acid and the ${ }^{14} \mathrm{C}$ age of the obtained $\mathrm{CO}_{2}$ was determined. These determinations were made at the Radiocarbon Dating Laboratory, Lund University, Sweden. Calibration was made according to Stuiver (1998).

\section{RESULTS}

\section{Sediment characteristics}

The sediment type at the stations was mostly muddy sand, with varying percentages of fine sediment (21 to $46 \%$ ) at water depths down to $130 \mathrm{~m}$ (Table 1). The most coarse sediment was encountered at Stn KA2. At Stn KA1, with a water depth of ca. $350 \mathrm{~m}$, the sea bed was muddy.

The sedOC was generally highest at the surface and decreased with depth into the sediment (Fig. 2). Surface concentrations were 0.15 to $0.20 \%$ (dry wt), except at Stn KA1 where the surface concentration was 0.55 to $0.60 \%$. Surficial sedOC at the shelf stations of the present study was lower than the mean value of $0.71 \%$ recently reported for surface sediments of deeper stations in depressions of the northern Aegean (Lykousis et al. 2002). SedOC in this study approached values of 0.10 to $0.12 \%$ at depth in the cores, except at Stn KA1 where a value of 0.33 to $0.34 \%$ was approached. These sedOC concentrations at depth in the cores were used (together with sediment accumulation rates) to calculate organic carbon burial rates.

SedIC concentrations were rather constant with depth into the sediment. The sedIC values at depth ranged from $2.2 \%$ at Stn KA1 to $4.0 \%$ at Stn KA2. These latter concentrations were used to calculate inorganic carbon burial rates. 


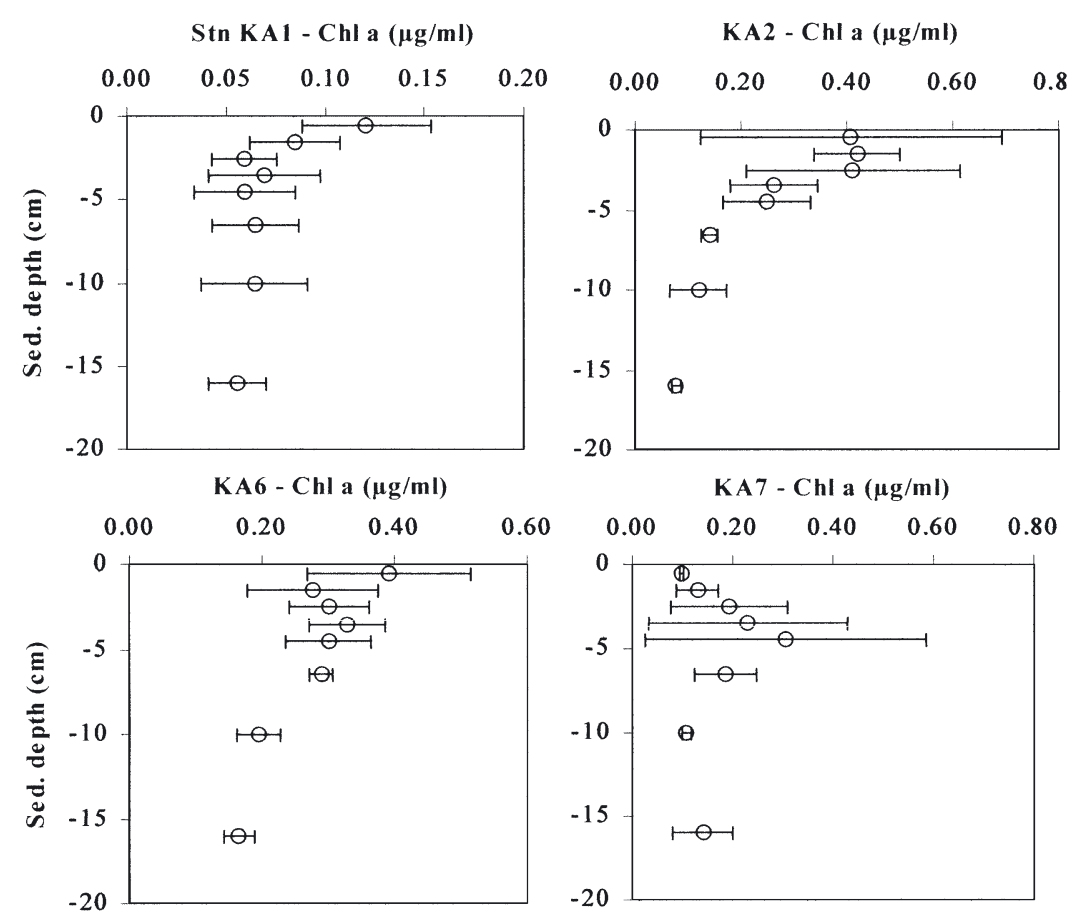

Fig. 3. Chl $a$ in the sediment during spring 2000 ( $\mu \mathrm{g} \mathrm{chl} \mathrm{a} \mathrm{ml}^{-1}$ wet sediment). Each profile is the mean of 2 to 5 multiple cores. Error bars denote $\pm 1 \mathrm{SD}$ ably higher (15 to $19 \mathrm{~cm} \mathrm{kyr}^{-1}$ ) than at the other stations (3.6 to $5.6 \mathrm{~cm} \mathrm{kyr}^{-1}$ ). KA1 was also the station with the most finegrained and muddy sediment.

The sedOC and sedIC contents below the mixed-layer depth, together with sediment accumulation rate $(\omega)$ and dry bulk density (DBD) from the same depth, were used to calculate the burial rate of organic and inorganic carbon (Eq. 1):

$$
\text { Burial rate }=\omega \times \mathrm{DBD} \times \operatorname{sedC}
$$

where sedC is the organic or inorganic carbon content. The organic carbon burial rates ranged from $6.0 \times 10^{-3}$ at $\mathrm{Stn}$ KA2 to $0.11 \mathrm{mmol} \mathrm{C} \mathrm{m} \mathrm{m}^{-2} \mathrm{~d}^{-1}$ at Stn KA1 (Table 2). The organic carbon burial rates were considerably higher at Stn KA1 (0.09 to $0.11 \mathrm{mmol} \mathrm{C} \mathrm{m}^{-2} \mathrm{~d}^{-1}$ ) than at the other stations $\left(6.0\right.$ to $10 \times 10^{-3} \mathrm{mmol} \mathrm{C} \mathrm{m}^{-2}$ $\mathrm{d}^{-1}$ ). The inorganic carbon burial rates ranged from 0.21 to $0.70 \mathrm{mmol} \mathrm{C} \mathrm{m} \mathrm{m}^{-1}$ (Table 2). Again, the highest rates were found at Stn KA1 (0.66 to $0.70 \mathrm{mmol} \mathrm{C} \mathrm{m}^{-2}$ $\left.\mathrm{d}^{-1}\right)$.
Measurements of chl a distributions in the sediment were made only during the spring 2000 cruise. Two to 5 replicate chlorophyll profiles were measured at each station. The chlorophyll concentrations decreased with depth into the sediment at most stations (Fig. 3). However, at Stn KA7 there was a subsurface maximum at ca. $5 \mathrm{~cm}$ depth. Surface concentrations ranged from ca. $0.10 \mu \mathrm{g} \mathrm{ml}^{-1}$ at Stns KA1 and KA7 to ca. $0.70 \mu \mathrm{g} \mathrm{ml}^{-1}$ at Stn KA3 (Fig. 3). The chlorophyll profiles did not indicate any mixing of the sediment below $10 \mathrm{~cm}$ depth.

\section{Sediment accumulation and carbon burial}

The ${ }^{14} \mathrm{C}$ age of the sediment at 14 to $16 \mathrm{~cm}$ depth in the cores was 1026, 841, 4216, 2756 and 3566 yr before present (BP) at Stns KA1 (sampled fall 1999), KA1 (sampled spring 2000), KA2, KA6 and KA7, respectively. The uncertainty of the age determination was \pm 90 to $100 \mathrm{yr}$. As evidenced by, e.g. sedimentary chlorophyll distributions, the examined depth (14 to $16 \mathrm{~cm}$ ) was well below the mixed layer of the sediment. By assuming a constant accumulation through time, the calculated sediment accumulation rates to a depth of $15 \mathrm{~cm}$ ranged from 3.6 to $19 \mathrm{~cm} \mathrm{kyr}^{-1}$ (Table 2). The sediment accumulation rate at Stn KA1 was consider-

\section{Benthic fluxes of $\mathrm{O}_{2}, \mathrm{C}_{\mathrm{T}}, \mathrm{A}_{\mathrm{T}}$ and DOC}

A total of $23 \mathrm{O}_{2}, 22 \mathrm{C}_{\mathrm{T}}$ and $10 \mathrm{~A}_{\mathrm{T}}$ fluxes were measured in situ with the benthic lander during 9 deployments on the 5 different stations during the 2 expeditions. Typical examples of the measured concentration change of $\mathrm{O}_{2}$ and $\mathrm{C}_{\mathrm{T}}$ versus time in the chambers are given in Fig. 4. The slope of this plot was used to calculate the benthic flux. Individual chamber $\mathrm{O}_{2}$ fluxes on the 2 cruises ranged from 1.14 to $6.94 \mathrm{mmol} \mathrm{O}_{2} \mathrm{~m}^{-2}$ $\mathrm{d}^{-1}$, whereas the $\mathrm{C}_{\mathrm{T}}$ fluxes ranged from 0.84 to 5.21

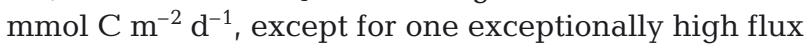
of $10.8 \mathrm{mmol} \mathrm{C} \mathrm{m}^{-2} \mathrm{~d}^{-1}$ at Stn KA7 (Table 2). The average of all measured $\mathrm{O}_{2}$ fluxes was $3.75 \pm 1.08( \pm \mathrm{SD})$ mmol $\mathrm{O}_{2} \mathrm{~m}^{-2} \mathrm{~d}^{-1}$, while the average of all measured $\mathrm{C}_{\mathrm{T}}$ fluxes was $2.85 \pm 0.68 \mathrm{mmol} \mathrm{C} \mathrm{m}^{-2} \mathrm{~d}^{-1}$. There was no significant concentration change of $\mathrm{A}_{\mathrm{T}}$ in the chambers during any of the deployments.

Since the syringes used on the chambers during these cruises were found to be a source of DOC contamination (Ståhl et al. 2004a), benthic DOC fluxes could not be measured in situ but were calculated from sediment porewater gradients. Porewater profiles of DOC from the stations are shown in Fig. 5a, and the corresponding $\mathrm{C}_{\mathrm{T}}$ profiles are presented in Fig. 5b. The porewater DOC concentration was typically ca. 100 $\mu \mathrm{M}$ in the surficial sediment, increasing to ca. $500 \mu \mathrm{M}$ 
Table 2. In situ measured fluxes of $\mathrm{O}_{2}$ and total carbonate $\left(\mathrm{C}_{T}\right)$, apparent respiration ratios $\left(\mathrm{C}_{\mathrm{T}}\right.$ flux: $\mathrm{O}_{2}$ flux $)$, sediment accumulation rates (based on ${ }^{14} \mathrm{C}$ dating), and organic and inorganic carbon burial rates at the various stations in the northern Aegean. B: black; G: green; W: white; R: red. nm: not measured

\begin{tabular}{|c|c|c|c|c|c|c|c|}
\hline Stn/yr & Chamber ID & $\begin{array}{c}\mathrm{O}_{2} \text { flux } \\
\left(\mathrm{mmol} \mathrm{m}^{-2} \mathrm{~d}^{-1}\right)\end{array}$ & $\begin{array}{c}\mathrm{C}_{\mathrm{T}} \text { flux } \\
\left(\mathrm{mmol} \mathrm{m}^{-2} \mathrm{~d}^{-1}\right)\end{array}$ & $\mathrm{C}_{\mathrm{T}}$ flux: $\mathrm{O}_{2}$ flux & $\begin{array}{c}\text { Sediment } \\
\text { accumulation } \\
\text { rate }\left(\mathrm{cm} \mathrm{kyr}^{-1}\right)\end{array}$ & $\begin{array}{c}\text { Organic C } \\
\text { burial rate } \\
\left(\mathrm{mmol} \mathrm{m}^{-2} \mathrm{~d}^{-1}\right)\end{array}$ & $\begin{array}{c}\text { Inorganic } \mathrm{C} \\
\text { burial rate } \\
\left(\mathrm{mmol} \mathrm{m}^{-2} \mathrm{~d}^{-1}\right)\end{array}$ \\
\hline KA1/99 & $\begin{array}{l}\text { B } \\
\text { G } \\
\text { W }\end{array}$ & $\begin{array}{l}-1.21 \\
-1.32 \\
-1.14\end{array}$ & $\begin{array}{l}1.16 \\
1.43 \\
1.55\end{array}$ & $\begin{array}{l}0.96 \\
1.08 \\
1.35\end{array}$ & 15 & 0.088 & 0.662 \\
\hline KA7/99 & $\begin{array}{l}\operatorname{IMBC}^{\mathrm{a}} \\
\mathrm{IMBC}^{\mathrm{a}}\end{array}$ & $\begin{array}{l}-6.94 \\
-3.95\end{array}$ & $\begin{array}{l}10.8 \\
2.57\end{array}$ & $\begin{array}{l}1.56 \\
0.65\end{array}$ & 4.3 & 0.009 & 0.209 \\
\hline KA2/99 & $\begin{array}{l}\mathrm{B} \\
\mathrm{G}\end{array}$ & $\begin{array}{l}-3.28 \\
-3.49\end{array}$ & $\begin{array}{c}\mathrm{bm} \\
1.68\end{array}$ & $\begin{array}{c}\mathrm{bm} \\
0.48\end{array}$ & 3.6 & 0.006 & 0.246 \\
\hline KA1/00 & $\begin{array}{l}\mathrm{B} \\
\mathrm{G}\end{array}$ & $\begin{array}{l}-1.72 \\
-3.04\end{array}$ & $\begin{array}{l}2.38 \\
2.48\end{array}$ & $\begin{array}{l}1.38 \\
0.82\end{array}$ & 19 & 0.106 & 0.705 \\
\hline $\mathrm{KA} 3 / 00$ & $\begin{array}{l}\mathrm{R} \\
\mathrm{B} \\
\mathrm{G}\end{array}$ & $\begin{array}{l}-2.61 \\
-3.86 \\
-4.13\end{array}$ & $\begin{array}{l}0.84 \\
3.05 \\
5.13\end{array}$ & $\begin{array}{l}0.32 \\
0.79 \\
1.24\end{array}$ & $\mathrm{~nm}$ & $\mathrm{~nm}$ & $\mathrm{~nm}$ \\
\hline $\begin{array}{l}\text { KA6/00 } \\
\text { 1st deployment }\end{array}$ & $\begin{array}{l}\mathrm{B} \\
\mathrm{G} \\
\mathrm{W}\end{array}$ & $\begin{array}{l}-2.39 \\
-3.89 \\
-5.02\end{array}$ & $\begin{array}{l}2.73 \\
3.01 \\
3.61\end{array}$ & $\begin{array}{l}1.14 \\
0.77 \\
0.72\end{array}$ & 5.6 & 0.010 & 0.234 \\
\hline $\mathrm{KA} 2 / 00$ & $\begin{array}{l}\mathrm{R} \\
\mathrm{B} \\
\mathrm{G} \\
\mathrm{W}\end{array}$ & $\begin{array}{l}-4.63 \\
-3.36 \\
-4.59 \\
-4.54\end{array}$ & $\begin{array}{l}1.21 \\
4.72 \\
3.38 \\
5.21\end{array}$ & $\begin{array}{l}0.26 \\
1.40 \\
0.74 \\
1.15\end{array}$ & $\mathrm{~nm}$ & $\mathrm{~nm}$ & $\mathrm{~nm}$ \\
\hline $\begin{array}{l}\text { KA6/00 } \\
\text { 2nd deployment }\end{array}$ & $\begin{array}{l}\mathrm{R} \\
\mathrm{B} \\
\mathrm{G} \\
\mathrm{W}\end{array}$ & $\begin{array}{l}-3.67 \\
-3.67 \\
-2.50 \\
-5.14\end{array}$ & $\begin{array}{l}1.72 \\
3.07 \\
2.27 \\
3.55\end{array}$ & $\begin{array}{l}0.47 \\
0.84 \\
0.91 \\
0.69\end{array}$ & $5.6^{\mathrm{b}}$ & $0.010^{\mathrm{b}}$ & $0.234^{\mathrm{b}}$ \\
\hline
\end{tabular}

at depth in the cores, except at Stn KA1 where a concentration of ca. $1000 \mu \mathrm{M}$ was approached at depth. The procedure used to calculate benthic DOC fluxes from porewater DOC gradients was thoroughly explained in Ståhl et al. (2004b). Briefly, Fick's first law of diffusion applied to sediments (Berner 1980) was used together with an apparent transport coefficient $\left(D_{\text {app }}\right)$, including both molecular diffusion as well as influence of biodiffusion and bioirrigation. The difference between the in situ measured and the porewater gradient-calculated diffusive $\mathrm{C}_{\mathrm{T}}$ flux was assumed to be caused by macrofaunal activities (i.e. bioirrigation and bioturbation) in the sediment. A bioirrigation/ biodiffusion factor $(\alpha)$ was obtained as the ratio between measured and diffusive $\mathrm{C}_{\mathrm{T}}$ fluxes. The obtained $\alpha$ ranged from 1.0 to 2.0, with 1 high value of 5.0 (Table 3 ). The $D_{\text {app }}$ for DOC was calculated by multiplying this $\alpha$ with the whole sediment molecular diffusion coefficent for DOC. As for Skagerrak sediments (Ståhl et al. 2003b), we assume that $65 \%$ of the porewater DOC in the Aegean sediments was present in the $3 \mathrm{kDa}$ fraction and $35 \%$ in the $100 \mathrm{kDa}$ fraction. This gave an average molecular diffusion coefficient in seawater $\left(D_{\mathrm{sw}}\right)$ of $1.71 \times 10^{-6} \mathrm{~cm}^{-2} \mathrm{~s}^{-1}$ at $25^{\circ} \mathrm{C}$ (Burdige et al. 1992, and references therein), which was corrected for in situ temperature $\left(14\right.$ to $\left.17^{\circ} \mathrm{C}\right)$. The calculated DOC fluxes thus obtained ranged from 0.11 to $0.74 \mathrm{mmol} \mathrm{C} \mathrm{m}^{-2} \mathrm{~d}^{-1}$ at the various stations (Table 3 ), with an average of $0.42 \pm 0.26 \mathrm{mmol} \mathrm{C} \mathrm{m}^{-2} \mathrm{~d}^{-1}$.

The average $\mathrm{O}_{2}, \mathrm{C}_{\mathrm{T}}$ and DOC fluxes measured/calculated at all stations during the 2 cruises are displayed in Fig. 6 together with their respective SDs. Stns KA1 and KA2 were the only stations visited in both fall and spring. At both stations, $\mathrm{O}_{2}, \mathrm{C}_{\mathrm{T}}$ and DOC fluxes were significantly higher in spring than in fall.

\section{Biomass of macrofauna in the chambers}

The sediment collected by the chambers of the lander after 10 chamber incubations was analyzed for macrofauna. A total of 149 taxa were identified. These belonged to Polychaeta (54\%), Mollusca $(13 \%)$, Crustacea $(21 \%)$, Echinodermata $(3.4 \%)$ and miscellanea minor phyla $(8.7 \%)$. The distribution of 

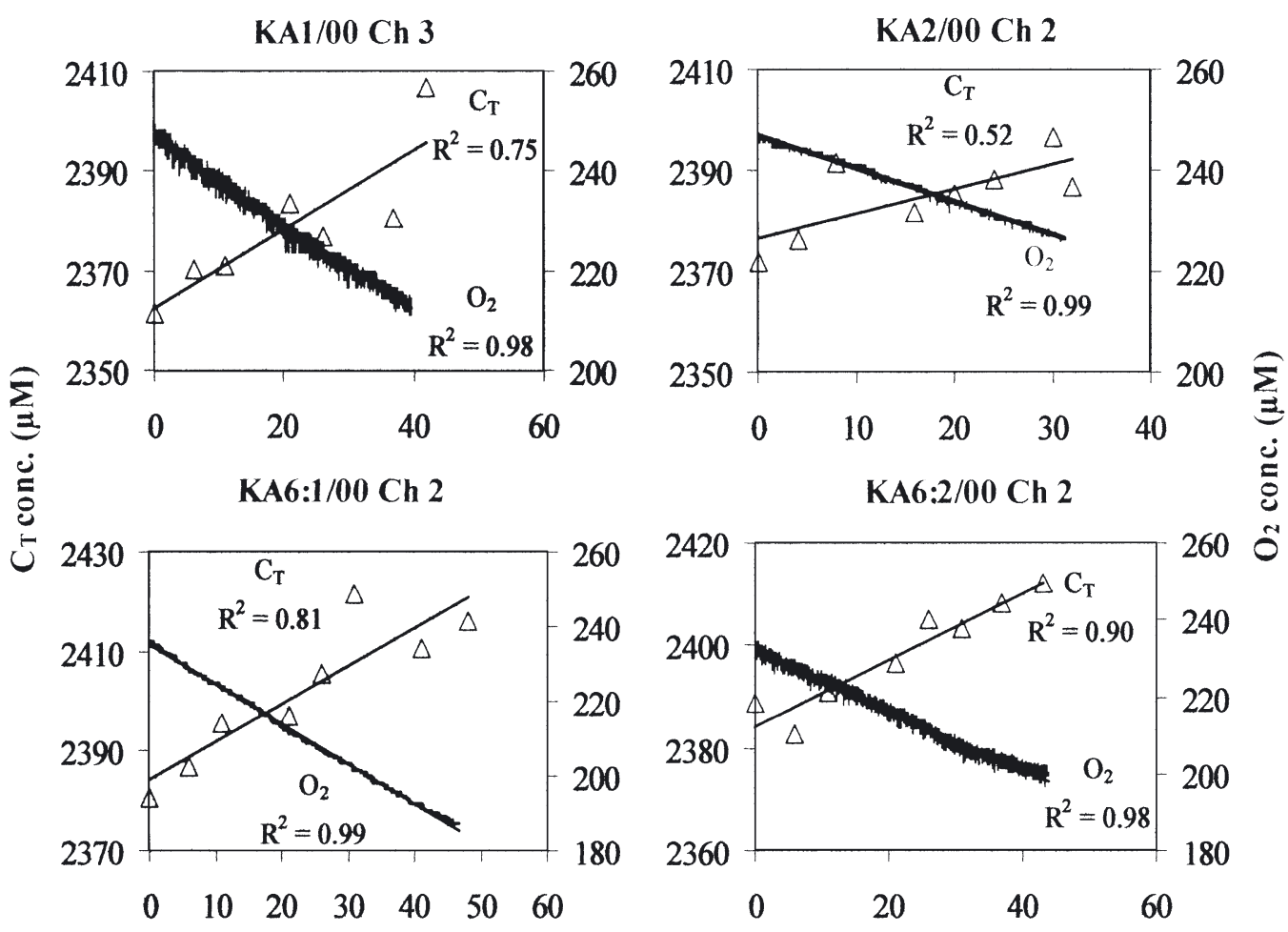

Time (h)

Fig. 4. Typical examples of benthic flux incubations made in situ with the Göteborg benthic lander. Total carbonate $\left(\mathrm{C}_{\mathrm{T}} \dot{\Delta}\right)$ was determined on board ship (at $\sim 20^{\circ} \mathrm{C}$ ) in water sampled by the lander. The best-fit line (straight line) to the $\mathrm{C}_{\mathrm{T}}$ data points is drawn. The $\mathrm{O}_{2}$ concentration (jagged line) was measured in situ with Clarke Type $\mathrm{O}_{2}$ electrodes. Stn:deployment no./year and chamber $(\mathrm{Ch})$ no.

individuals was similar among polychaetes, molluscs and echinoderms. The polychaete Levinsenia gracilis was abundant, and made up ca. $10 \%$ of the total population. The total biomass of animals $>0.5 \mathrm{~mm}$ of all species found in the chamber sediments ranged from ca. $0.58 \times 10^{-2}$ to $0.38 \mathrm{~g}$ dry wt per chamber, which corresponds to 0.14 to $9.41 \mathrm{~g}$ dry $\mathrm{wt} \mathrm{m}^{-2}$. The average faunal biomass in the chamber sediments was $2.93 \pm$ $2.62 \mathrm{~g}$ dry wt $\mathrm{m}^{-2}$, including all measurements, and the high SD indicated some non-negligible spatial variability of the distribution of faunal biomass in these sediments. Vertical distribution pattern for biomass at Stn KA6 exhibited maxima at the subsurface layer (2 to $6 \mathrm{~cm}$ ) attributed mainly to polychaetes, whereas at Stn KA1 the peak was observed even deeper (6 to $10 \mathrm{~cm}$ layer), attributed to echinoderms and crustaceans. The small-sized animals (0.5 to $1 \mathrm{~mm}$ ) were mostly limited to the upper $2 \mathrm{~cm}$ layer.

Table 3. Station mean diffusive (gradient) and total (in situ chamber) carbonate $\left(\mathrm{C}_{\mathrm{T}}\right)$ fluxes were used for calculating a biodiffusion/bioirrigation factor $(\alpha)$. Dissolved organic carbon (DOC) fluxes were calculated using Fick's first law and an apparent transport coefficient $\left(D_{\text {app }}\right)$ which was obtained by multiplying the whole sediment molecular diffusion coefficient $\left(D_{\text {sed }}\right)$ for DOC with $\alpha_{i}$ if the diffusive flux was > total flux, $\alpha$ was set to $1 . \mathrm{DOC} / \mathrm{C}_{\mathrm{T}}$ is the $\mathrm{DOC}$ flux as percentage of the mean total $\mathrm{C}_{\mathrm{T}}$ flux at each station

\begin{tabular}{|lccccc|}
\hline Stn/yr & $\begin{array}{c}\text { Diffusive } \mathrm{C}_{\mathrm{T}} \text { flux } \\
\left(\mathrm{mmol} \mathrm{m}^{-2} \mathrm{~d}^{-1}\right)\end{array}$ & $\begin{array}{c}\text { Total C } \mathrm{Tlux} \\
\left(\mathrm{mmol} \mathrm{m}^{-2} \mathrm{~d}^{-1}\right)\end{array}$ & $\alpha$ & $\begin{array}{c}\text { Calculated DOC flux } \\
\left(\mathrm{mmol} \mathrm{m}^{-2} \mathrm{~d}^{-1}\right)\end{array}$ & $\begin{array}{c}\text { DOC/C } \\
(\%)\end{array}$ \\
\hline KA1/99 & 1.76 & 1.38 & 1.00 & 0.11 & 7.8 \\
KA7/99 & 1.33 & 6.69 & 5.04 & 0.48 & 7.2 \\
KA2/99 & 1.42 & 1.68 & 1.18 & 0.22 & 27 \\
KA1/00 & 1.20 & 2.43 & 2.03 & 0.67 & 9.8 \\
KA6/00 & 3.37 & 2.85 & 1.00 & 0.28 & 20 \\
KA2/00 & 1.84 & 3.63 & 1.97 & 0.74 & \\
\hline
\end{tabular}




\section{DISCUSSION}

\section{Benthic respiration rates in the northern Aegean Sea}

Both organic carbon oxidation and calcium carbonate dissolution produce $\mathrm{C}_{\mathrm{T}}$ in the sediment, which can be transported across the sediment-water interface and form the benthic $\mathrm{C}_{\mathrm{T}}$ flux (e.g. Anderson et al. 1986, Berelson et al. 1996, Mucci et al. 2000, Silverberg et al. 2000, Ståhl et al. 2003a). As $\mathrm{CaCO}_{3}$ dissolution is the most likely process generating alkalinity in sediments with low oxygen consumption, and hence presumably a minor extent of anoxic remineralization of organic matter, the non-measurable chamber fluxes of $A_{T}$ might be explained with $\mathrm{CaCO}_{3}$ dissolution being of minor importance in these sediments. We have therefore used the $\mathrm{C}_{\mathrm{T}}$ fluxes as a measure of organic carbon oxidation, or benthic respiration, in this study.

Rates of organic carbon oxidation $\left(\mathrm{C}_{\mathrm{ox}}\right)$, and their spatial and temporal variability, have to our knowledge not previously been determined in shelf sediments of the northern Aegean Sea. The average of the 22 individual in situ chamber measured $\mathrm{C}_{\mathrm{T}}$ fluxes in this study $\left(2.85 \pm 0.68 \mathrm{mmol} \mathrm{C} \mathrm{m}^{-2}\right.$ $\mathrm{d}^{-1}$ ) is in the low range of $\mathrm{C}_{\mathrm{ox}}$ rates in other continental margin sediments. Ståhl et al. (2003b) reported in situ rates from the mesotrophic Skagerrak (water depth 112 to $562 \mathrm{~m}$ ) of $8.60 \pm 4.43 \mathrm{mmol} \mathrm{C} \mathrm{m}^{-2} \mathrm{~d}^{-1}$ (average $\pm \mathrm{SD}$ ). In 3 Arctic fjords around Svalbard at water depths of 115 to $175 \mathrm{~m}$, Glud et al. (1998) used in situ determined $C_{T}$ fluxes as a measure of $\mathrm{C}_{\mathrm{ox}}$ rates and found them to range from 8.80 to $19.8 \mathrm{mmol} \mathrm{C}$ $\mathrm{m}^{-2} \mathrm{~d}^{-1}$ (average of all measurements $13.7 \mathrm{mmol} \mathrm{C} \mathrm{m}{ }^{-2} \mathrm{~d}^{-1}$ ). Hartnett \& Devol (2003) obtained $\mathrm{C}_{\mathrm{ox}}$ rates of 8.18 to $19.8 \mathrm{mmol} \mathrm{C} \mathrm{m}^{-2} \mathrm{~d}^{-1}$ (average of all stations $12.9 \mathrm{mmol} \mathrm{C} \mathrm{m}^{-2} \mathrm{~d}^{-1}$ ) in continental shelf sediments of the eastern Pacific off Washington State at water depths of 85 to $239 \mathrm{~m}$ (14 stations with bottom water oxygen above $100 \mu \mathrm{M})$. In continental margins sediments off Chile at water depths of 34 to $606 \mathrm{~m}$, Glud et al. (1999) measured $\mathrm{C}_{\mathrm{ox}}$ rates in situ and found them to be in the range of 10.6 to $163 \mathrm{mmol} \mathrm{C} \mathrm{m}^{-2} \mathrm{~d}^{-1}$ (station average $55.0 \mathrm{mmol} \mathrm{C} \mathrm{m}^{-2} \mathrm{~d}^{-1}$ ). However, as the coastal waters off Chile are
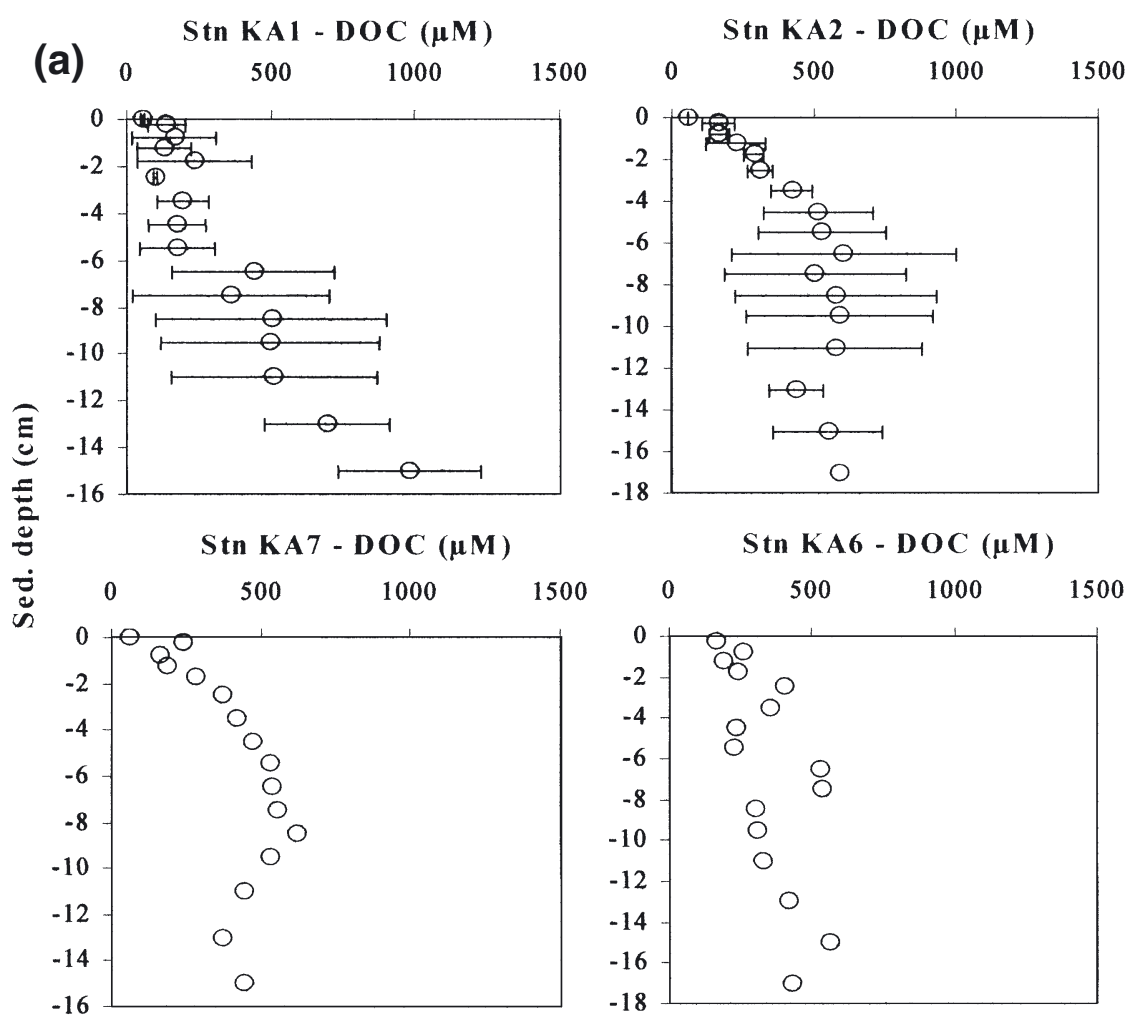

(b)
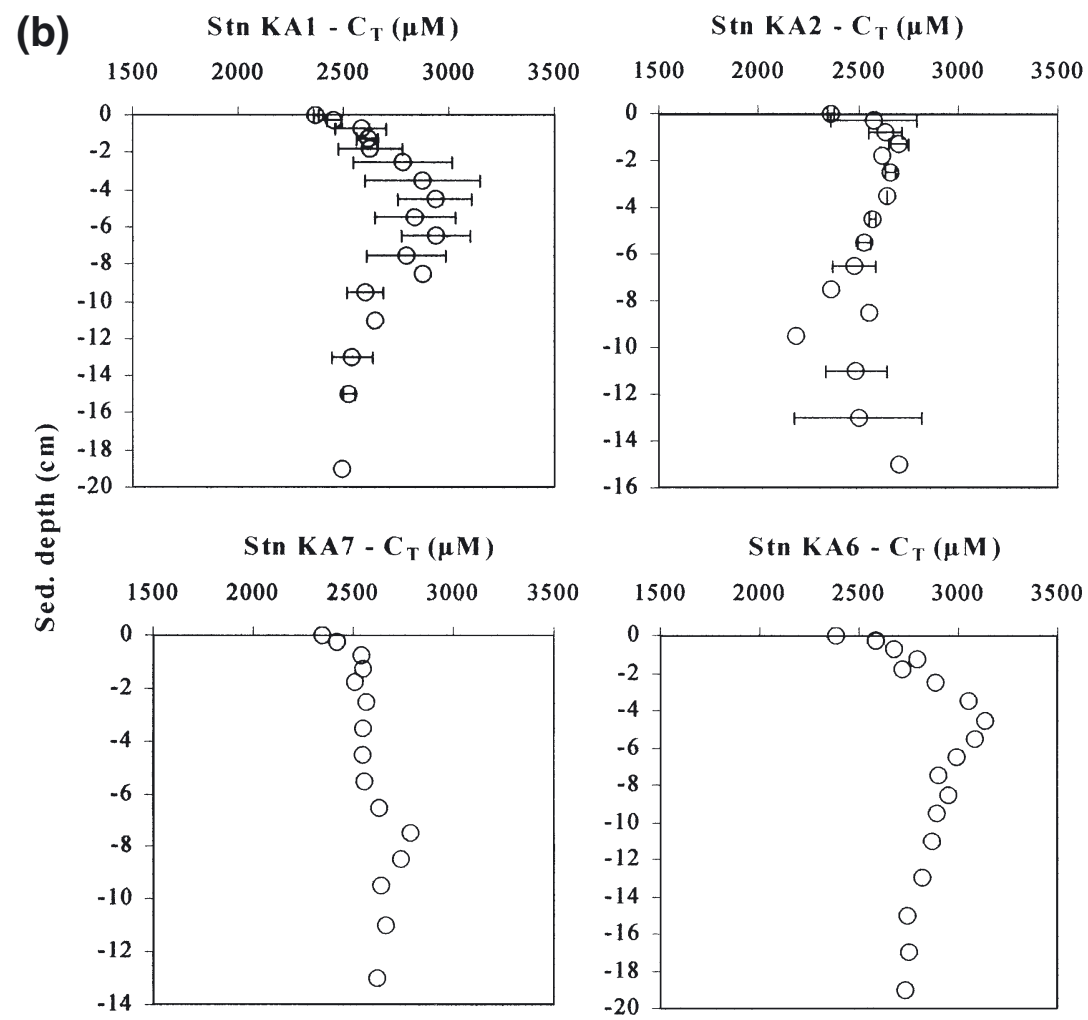

Fig. 5. Porewater profiles of (a) dissolved organic carbon (DOC) and (b) total carbonate $\left(\mathrm{C}_{\mathrm{T}}\right)$ in northern Aegean sediments. Error bars denote \pm 1 SD. At each station, 1 to 2 profiles were measured 


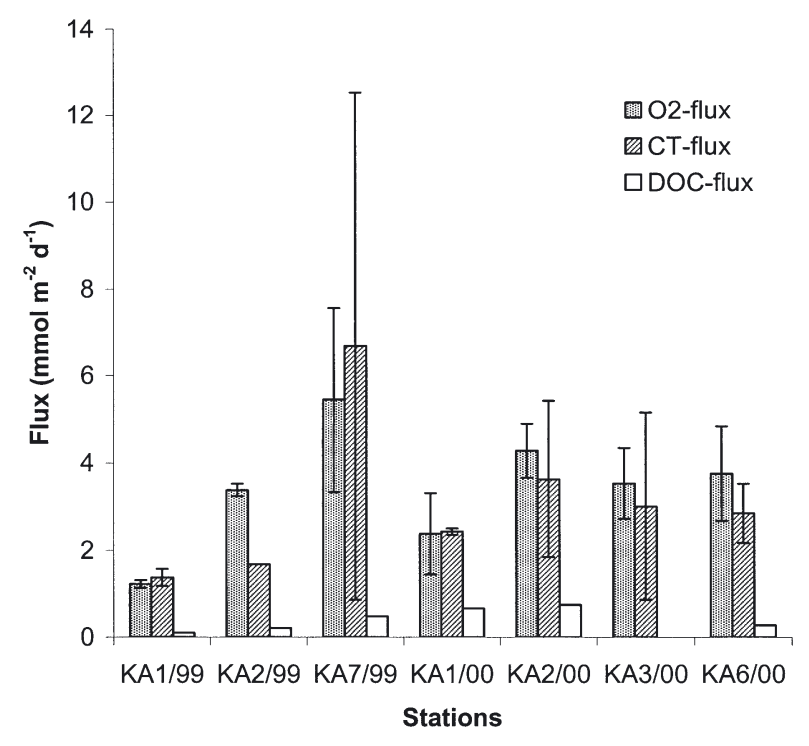

Fig. 6. Measured $\mathrm{O}_{2}$ and total carbonate $\left(\mathrm{C}_{\mathrm{T}}\right)$ fluxes, as well as calculated dissolved organic carbon (DOC) fluxes, at the 5 stations. Stns KA1 and KA2 were visited during both the fall 1999 and the spring 2000 cruise; KA6 was visited twice during the spring 2000 cruise; KA3 and KA7 were visited once. Error bars denote $\pm 1 \mathrm{SD} ; \mathrm{x}$-axis labels are given as $\mathrm{Stn} / \mathrm{yr}$

characterized by upwelling and high primary productivity, high benthic respiration rates are also expected.

Oxygen uptake rate is another measure of benthic respiration. Oxygen uptake rates of 1.22 to $2.86 \mathrm{mmol}$ $\mathrm{O}_{2} \mathrm{~m}^{-2} \mathrm{~d}^{-1}$ (average of 4 measurements $1.66 \mathrm{mmol} \mathrm{O}_{2}$ $\mathrm{m}^{-2} \mathrm{~d}^{-1}$ ) were measured in situ at 2 deep stations in depressions of the northern Aegean at water depths of 975 to $1270 \mathrm{~m}$ (Lykousis et al. 2002). The average of the 23 individual in situ measured $\mathrm{O}_{2}$ fluxes in the northern Aegean shelf sediments of this study (water depths 80 to $354 \mathrm{~m}$ ) was $3.75 \pm 1.08 \mathrm{mmol} \mathrm{O}_{2} \mathrm{~m}^{-2} \mathrm{~d}^{-1}$. This is higher than the oxygen uptake rates of the northern Aegean deep depression sediments, but lower than those typically measured ( 4 to $30 \mathrm{mmol} \mathrm{O}_{2} \mathrm{~m}^{-2} \mathrm{~d}^{-1}$ ) in many other continental margin sediments (e.g. Hall et al. 1989, Archer \& Devol 1992, Rasmussen \& Jørgensen 1992, Hulth et al. 1994, Tahey et al. 1994, Glud et al. 1998, 2003, Ståhl et al. 2004b). The oxygen fluxes into Aegean Sea sediments were similar to those into margin sediments of the southern Weddell Sea, Antarctica (Hulth et al. 1997) and into deep-sea sediments, where oxygen fluxes typically are lower and often 0.5 to 3 mmol m${ }^{-2} \mathrm{~d}^{-1}$ (e.g. Pfannkuche 1993, Jahnke 1996, Smith et al. 1997, Aller et al. 1998, Wenzhöfer \& Glud 2002 and references therein, Ståhl et al. 2004a). Obviously, the oligotrophic character and low primary productivity of the Aegean Sea is reflected in the benthic respiration rates (measured both as $\mathrm{O}_{2}$ uptake and $\mathrm{C}_{\mathrm{T}}$ efflux) being lower than in more productive continental margin environments, and approaching those of deep-sea localities.

Black Sea water (BSW) enters the northern Aegean Sea through the Dardanelles Strait (Fig. 1). The mixing of BSW with the underlying Levantine Intermediate Water leads to the creation of thermohaline fronts and related jets nearby the Lemnos Island (Zervakis et al. 2000), which might influence phytoplanktonic community composition and primary productivity. Also, significant amounts of terrestrial organic matter is presumably transported into the northern Aegean Sea with the BSW. The influence of BSW on the northern Aegean was not reflected in any observable spatial variability of the measured benthic respiration rates. There was no significant difference of these rates between stations during either fall 1999 or spring 2000 (Fig. 6). There was no significant difference in organic carbon burial rates between the stations either (Table 2), except for high burial at the muddy Stn KA 1 (Table 1). More measurements with greater spatial resolution are probably necessary before any influence of BSW on benthic organic carbon recycling and burial in the northern Aegean can be fully evaluated.

Two of the stations (KA1 and KA2) were visited both in fall 1999 and in spring 2000. For these stations it was possible to determine if there was any temporal variability of the benthic rates. For each station, $\mathrm{O}_{2}, \mathrm{C}_{\mathrm{T}}$ and DOC fluxes were all significantly higher during spring than in fall (Fig. 6, Table 2). However, measurements have to be carried out several times during more than a full annual cycle before interannual and seasonal variability of benthic organic carbon recycling rates in the northern Aegean can be distinguished.

The $\mathrm{C}_{\mathrm{T}}$ fluxes were positively correlated with the $\mathrm{O}_{2}$ uptake rates (Fig. 7). The average apparent respiration ratio, i.e. the average of all the individual $\mathrm{C}_{\mathrm{T}}$ flux: $\mathrm{O}_{2}$ flux ratios (Table 2 ), was $0.90 \pm 0.36$. Apparent respiration ratios clearly greater than 1 , which often are found

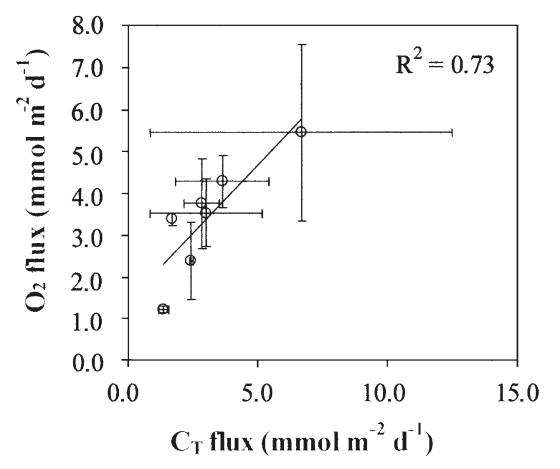

Fig. 7. Correlation between $\mathrm{O}_{2}$ and total carbonate $\left(\mathrm{C}_{\mathrm{T}}\right)$ fluxes. Station averages are plotted. Error bars denote $\pm 1 \mathrm{SD}$ 
in continental margin sediments, normally indicate that anoxic mineralisation of organic matter is important, and that either burial of some of the reduced products of anoxic mineralisation takes place or that the oxidation of them with oxygen is delayed (see Thamdrup \& Canfield 2000, and Ståhl et al. 2004b for recent discussions on this subject). In shelf sediments of the northern Aegean Sea, where nitrification rates are low (Brunnegård et al. unpubl. results) and where we have assumed oxygen consumption through ammonium oxidation to be negligible in relation to the total oxygen uptake, the low average apparent respiration ratio together with low sediment accumulation rates, low organic carbon contents, and low $\mathrm{C}_{\mathrm{T}}$ fluxes suggest that aerobic respiration clearly is the dominating pathway for organic carbon oxidation. The average apparent respiration ratio found for the Aegean Sea is actually very similar to a ratio of 0.85 , which often is used for deep-sea sediments (e.g. Smith 1978), and it is consistent with $\mathrm{CaCO}_{3}$ dissolution being of minor importance as suggested above.

\section{Influence of organic matter quality on respiration rates}

One important factor in controlling respiration rates in marine sediments is the quality of the degrading organic matter. Labile material such as phytodetritus has been found to be degraded much faster than the more refractory bulk organic matter (e.g.

Pfannkuche 1993, Ståhl et al. 2004b).

When correlating the $\mathrm{O}_{2}$ flux and the $\mathrm{C}_{\mathrm{T}}$ flux against the more labile fraction of organic carbon, and the mean chl a concentration in the surficial sediment was used as a tracer of this fraction, we obtained significant relationships in both cases (Fig. 8). This confirms that also in Aegean Sea sediments organic carbon oxidation rates were to a large extent controlled by the availability of labile phytodetrital organic matter. The finding that $\mathrm{O}_{2}$ and $\mathrm{C}_{\mathrm{T}}$ fluxes correlated equally well with chl a concentrations (Fig. 8) is consistent with benthic respiration being dominated by aerobic degradation in these sediments. In Skagerrak sediments, where anaerobic pathways contribute importantly to organic matter mineralization (e.g. Thamdrup \& Canfield 2000, and references therein), $C_{T}$ fluxes have been found to correlate considerably better with chl a concentrations than $\mathrm{O}_{2}$ fluxes (Ståhl et al. 2004b).

\section{Macrofauna and organic carbon recycling}

Another factor of importance for organic carbon recycling and benthic solute exchange in many coastal and shelf sediments is the presence of bioirrigating and bioturbating macrofauna (e.g. Aller 1982, Rutgers van der Loeff et al. 1984, Kristensen \& Blackburn 1987, Aller \& Aller 1998, Hulthe et al. 1998).

In northwestern Mediterranean continental shelf, slope and deep-sea sediments, Tahey et al. (1994) found a strong positive relation between macrofaunal density and the enhancement of oxygen fluxes over what could be accomplished by molecular diffusion. Glud et al. (1994) made a very similar observation using in situ measured oxygen fluxes and macrofaunal biomass in continental margin and deep-sea sediments of the south Atlantic off Namibia. However, the biomass of macrofauna (dry wt), collected from the benthic chambers in this study, showed no significant correlation with either the $\mathrm{O}_{2}$ fluxes or the $\mathrm{C}_{\mathrm{T}}$ fluxes measured in situ in the same chambers. This observation is consistent with a previous survey in the northern Aegean bathyal system (Tselepides et al. 2000), which did not find any apparent relationship between benthic macrofaunal and environmental parameters (such as chl a concentration, organic carbon, nitrogen and ATP content, as well as C:N-ratio) at different water depths. Also in shelf and slope sediments of the more productive Skagerrak, no significant correlation between macrofaunal biomass and $\mathrm{O}_{2}$ or $\mathrm{C}_{\mathrm{T}}$ fluxes was
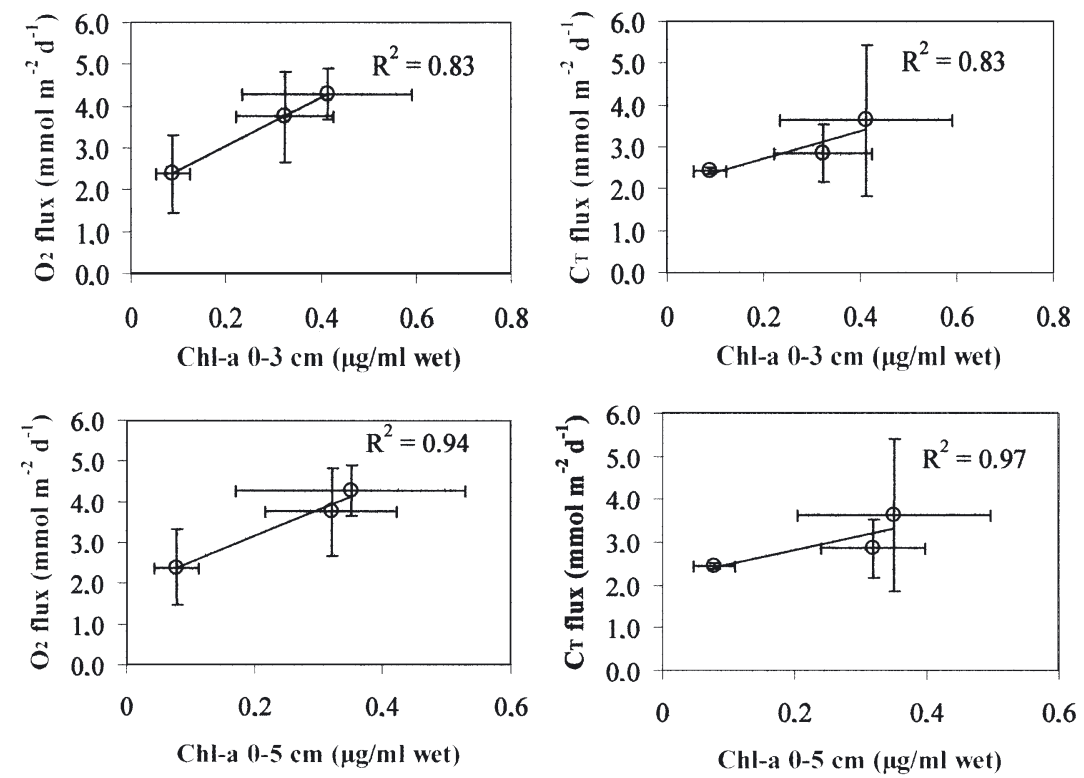

Fig. 8. (a) Station average $\mathrm{O}_{2}$ fluxes ( $\mathrm{n}=2$ to 4 ) versus average chl a concentration in the top 0 to 3 and top 0 to $5 \mathrm{~cm}$ of the sediment. (b) Station average benthic total carbonate $\left(\mathrm{C}_{\mathrm{T}}\right)$ fluxes $(\mathrm{n}=2$ to 4$)$ vs average chl a concentration in the top 0 to 3 and top 0 to $5 \mathrm{~cm}$ of the sediment. Error bars denote $\pm 1 \mathrm{SD}$ 
found (Ståhl et al. 2004b). This indicates that total dry wt biomass is not a sensitive measure of macrofaunal influence on organic carbon recycling in northern Aegean and Skagerrak sediments. However, the range of macrofaunal biomass in the present and the Skagerrak study may be too limited to have an observable influence on the measured benthic respiration rates. The investigations of Tahey et al. (1994) and Glud et al. (1994) were made from shallow to deep-sea sediments and hence the range of biomass (as well as of oxygen flux) encountered was much larger than in the present and the Skagerrak studies.

\section{Importance of benthic DOC fluxes}

The benthic DOC efflux is a component of sedimentary organic carbon recycling and the importance of this component in relation to organic carbon oxidation rates has been discussed intensively in recent years (e.g. Hall et al. 1990, Burdige et al. 1992, 1999, Skoog et al. 1996, Hulth et al. 1997, Alperin et al. 1999, Holcombe et al. 2001, Burdige 2002, Ståhl et al. 2004a,b).

The DOC fluxes estimated in this study accounted for the influence of biodiffusion and bioirrigation, ranged from 0.11 to $0.74 \mathrm{mmol} \mathrm{C} \mathrm{m}^{-2} \mathrm{~d}^{-1}$ with an average of $0.42 \pm 0.26 \mathrm{mmol} \mathrm{C} \mathrm{m} \mathrm{C} \mathrm{d}^{-1}$. This is similar to DOC fluxes of $0.15 \pm 0.09$ to $0.97 \pm 0.15 \mathrm{mmol} \mathrm{C} \mathrm{m}^{-2} \mathrm{~d}^{-1}$ estimated in the same way for continental margin sediments of the more productive Skagerrak (Ståhl et al. $2004 b)$. The DOC fluxes of this study are lower than fluxes measured in whole-core laboratory incubations from the estuarine Chesapeake Bay (Burdige \& Homestead $1994 ; 1.4$ to $2.9 \mathrm{mmol} \mathrm{C} \mathrm{m}^{-2} \mathrm{~d}^{-1}$ ), but higher than fluxes calculated from porewater gradients from the North Carolina continental slope (Alperin et al. 1999; $\sim 0.08 \mathrm{mmol} \mathrm{C} \mathrm{m}^{-2} \mathrm{~d}^{-1}$ ). They are in the lower range compared to in situ measured DOC fluxes, by benthic chambers, from the Gullmar Fjord, western Sweden (Skoog et al. 1996; 0 to $2.5 \mathrm{mmol} \mathrm{C} \mathrm{m}^{-2} \mathrm{~d}^{-1}$ ) and from California continental margin sediments (Burdige et al. 1999; 0.39 to $2.12 \mathrm{mmol} \mathrm{C} \mathrm{m}^{-2} \mathrm{~d}^{-1}$ ). Holcombe et al. (2001) investigated benthic DOC fluxes in the oxygen minimum zone along the northwestern Mexican continental margin. They obtained porewater gradient calculated fluxes, from sliced and centrifuged sediment cores, ranging from 0.13 to $0.43 \mathrm{mmol} \mathrm{C} \mathrm{m}^{-2} \mathrm{~d}^{-1}$, which agrees well with our range of values.

Even if the DOC fluxes generally increased with increasing $\mathrm{C}_{\mathrm{T}}$ fluxes in this study (data not shown), there was no statistically significant correlation between the 2 fluxes. The DOC flux was 7.2 to $27 \%$ of the $\mathrm{C}_{\mathrm{T}}$ flux (Table 3 ), with an average of $14 \pm 8.1 \%$. This relative importance of the DOC flux (i.e. the DOC flux divided by the $\mathrm{C}_{\mathrm{T}}$ flux) did not show any significant dependence on the magnitude of the $\mathrm{C}_{\mathrm{T}}$ flux, but it was somewhat higher than previously found for continental margin sediments (Alperin et al. 1999, 2\% ; Burdige et al. 1999, <10\%; Holcombe et al. 2001, 12\%; Ståhl et al. 2004 b, 3 to $10 \%$ ). For shelf sediments of the northern Aegean, we consider the contribution of the DOC flux to the overall recycling of organic carbon to be substantial. It is therefore important to include DOC fluxes when assessing carbon cycling and constructing organic carbon budgets, or mass balances, for these sediments.

\section{Benthic mass balances}

One of the aims of this study was to investigate the efficiency of northern Aegean shelf sediments to recycle and sequester organic carbon. One way of doing this is to construct benthic mass balances for organic carbon.

POC deposition rates to the sediment were calculated (Fig. 9) by adding the burial rates and the recycling rates for organic carbon, assuming steady state for the bacterial and faunal biomass pools in the sediment. The sum of the benthic $\mathrm{C}_{\mathrm{T}}$ and DOC flux was used as the net organic carbon recycling rate. Since the recycling rates can vary on a seasonal scale, whereas the burial rates are integrated over considerably longer time-scales, a combination of these 2 rates will be associated with uncertanties. Nevertheless, this approach has often been used to estimate POC deposition rates (e.g. Hall et al. 1990, Canfield 1993, 1994, Berelson et al. 1996, Hulth et al. 1997, Glud et al. 1998, Hartnett \& Devol 2003, Ståhl et al. 2004a,b) although the DOC flux has not always been considered previously when constructing such benthic mass balances. The POC deposition to the sediment calculated in this way ranged from 1.6 to $7.2 \mathrm{mmol} \mathrm{C} \mathrm{m}^{-2} \mathrm{~d}^{-1}$ for the various stations (average of $3.6 \pm 2.0 \mathrm{mmol} \mathrm{C} \mathrm{m}^{-2} \mathrm{~d}^{-1}$ ).

The burial efficiency, i.e. the fraction of the POC input which escapes degradation and is buried in the sediment, varied between 0.1 and $5.3 \%$ (Table 4 ), with a total mean of $1.6 \pm 2.2 \%$ for all stations. Stn KA1 differed from the other stations and exhibited a higher burial efficiency ( 3.1 to $5.3 \%$, average $4.2 \%$ ), whereas the burial efficiency for other stations was 0.1 to $0.4 \%$ (average $0.3 \%$ ). Stn KA1 also had the most finegrained sediment, highest sedOC content and highest organic carbon burial rates (Tables \& 2, Fig. 2). A separate mass balance was therefore constructed for Stn KA1, based on measurements made there on 2 seasons (fall and spring), whereas the similarity of the other stations justified one common mass balance (Fig. 9).

Compilations and evaluations of a large number of observations in various marine environments have 
shown that the burial efficiency (or \% organic carbon preserved) generally increase with sediment accumulation rates (Henrichs \& Reeburgh 1987, Canfield 1993, 1994). The obtained burial efficiency for Stn KA1 is within the range reported by these authors for the given sediment accumulation rate. However, the average burial efficiency for the other stations in this study is considerably lower than found in other sediments with similar sediment accumulation rates (see Table 4 for specific examples, and Henrichs \& Reeburgh 1987 and Canfield 1993, 1994 for a general comparison). The low degree of organic carbon sequestering observed in northern Aegean Sea sediments, with the exception of Stn KA1 in the south, may be explained by the transport conditions near the sea-bed (consisting of muddy sand) and with a dominant part of the POC input taking place through suspension-feeding animals. It is well-known that such animals play an important role in this type of coastal and shelf sediment, enhancing biodeposition rates of labile organic matter (e.g. Norkko et al. 2001). Most of the POC deposited in this way should pass the gut system of benthic animals, and their feacal material should be easily available for further bacterial degradation. This would provide an efficient recycling of the deposited material and a low degree of organic carbon sequestering.

Estimates of annual primary production for the northern Aegean Sea range from ca. $30 \mathrm{~g} \mathrm{C} \mathrm{m}^{-2} \mathrm{yr}^{-1}$ (Ignatiades et al. 2002) to $50-100 \mathrm{~g} \mathrm{C} \mathrm{m}^{-2} \mathrm{yr}^{-1}$ (Berger et al. 1989). Using $50 \mathrm{~g} \mathrm{C} \mathrm{m}^{-2} \mathrm{yr}^{-1}$ as a sound intermediate between these 2 estimates, the calculated average POC deposition rate to the sediment corresponds to $32 \%$ of the annual primary production, which agrees well with values of 25 to $50 \%$ given by Wollast (1991) for continental shelves. The average burial flux of organic carbon corresponded to $0.8 \%$ of the annual primary production and $4 \%$ of the average POC sea-floor deposition rate at Stn KA1, and to $0.07 \%$ of the annual primary production and $0.3 \%$ of the average POC seafloor deposition rate at the other stations (Fig. 9). This shows that organic carbon sequestering in sediments of the northern Aegean Sea is neither efficient nor can be a) Station KA 1

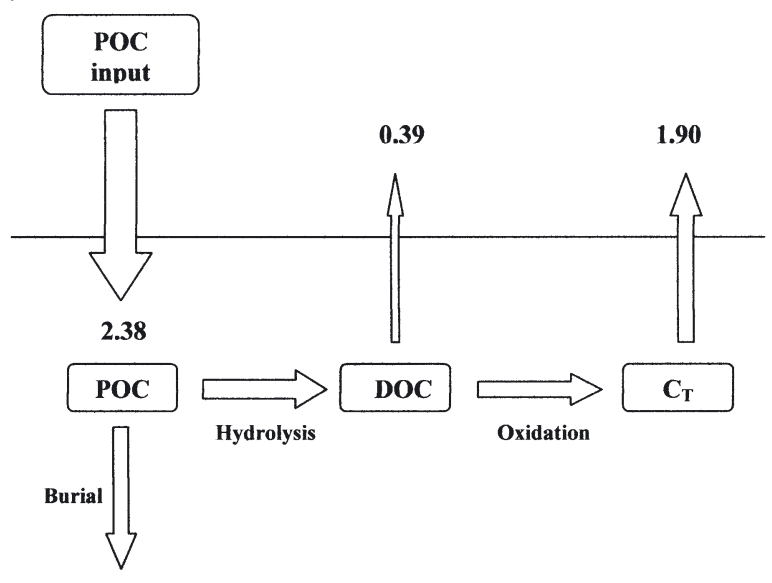

0.09

b)

Burial efficiency $4 \%$

Other stations

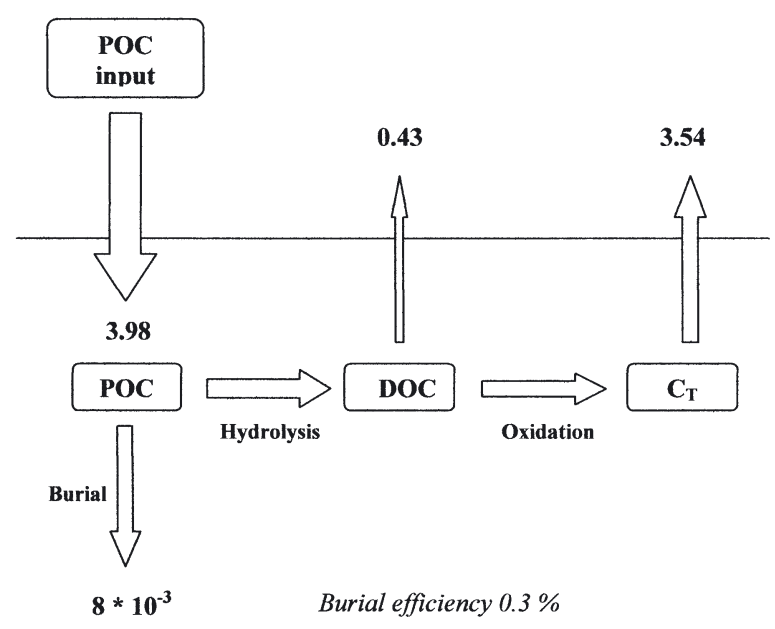

Fig. 9. Benthic organic carbon mass balances for (a) Stn KA1 and (b) the other stations. The average of all available dissolved organic carbon (DOC), total carbonate $\left(\mathrm{C}_{\mathrm{T}}\right)$ and burial fluxes, respectively, is given in each mass balance. Particulate organic carbon (POC) input was calculated as the sum of these 3 fluxes. The characteristics of Stn KA1 (grain size, sediment organic carbon content, sediment accumulation rate, etc.; see text) were different from the other stations, and it has therefore been treated separately. All fluxes are in $\mathrm{mmol} \mathrm{C} \mathrm{m}{ }^{-2} \mathrm{~d}^{-1}$

Table 4. Examples of contrasting continental margin environments with regard to sediment accumulation rates $(\omega)$ and organic carbon burial efficiencies $\left(\mathrm{OC}_{\text {bur. eff. }}\right)$

\begin{tabular}{|lcccc|}
\hline Area & Depth $(\mathrm{m})$ & $\omega\left(\mathrm{g} \mathrm{cm}^{-2} \mathrm{yr}^{-1}\right)$ & $\mathrm{OC}_{\text {bur. eff. }}(\%)$ & Source \\
\hline Northern Aegean Sea & $80-354$ & $3-13 \times 10^{-3}$ & $0.1-5$ & Present study \\
Skagerrak & $112-562$ & $0.12-0.63$ & $34-73$ & Ståhl et al. (2004b) \\
Arctic Ocean, Svalbard & $115-329$ & $0.10-0.47$ & $19-47$ & Glud et al. (1998) \\
Southern Weddell Sea & $280-648$ & $1.2-6.0 \times 10^{-4}$ & $12-43$ & Hulth et al. (1997) \\
Central California Borderland & $781-3592$ & $0.11-1.1 \times 10^{-3}$ & $2-49$ & Berelson et al. (1996) \\
Cape Lookout Bight & $6-10$ & 3.82 & $66-76$ & Martens et al. (1992) \\
Southern California Borderland & $\sim 900$ & 0.02 & 43 & Jahnke (1990) \\
\hline
\end{tabular}


considered quantitatively important in the carbon cycle of this oligotrophic continental margin environment.

\section{CONCLUSIONS}

(1) The measured benthic $\mathrm{C}_{\mathrm{T}}$ fluxes were positively correlated with the $\mathrm{O}_{2}$ uptake rates and were generally somewhat lower than the $\mathrm{O}_{2}$ uptake rates, giving an average apparent respiration ratio $\left(\mathrm{C}_{\mathrm{T}}\right.$ flux: $\mathrm{O}_{2}$ flux $)$ of $0.90 \pm 0.36$. This respiration ratio is similar to a ratio of 0.85 which often is used for deep-sea sediments, suggesting a clear dominance of aerobic respiration in these organic carbon-poor northern Aegean shelf sediments. (2) Temporal variability of the benthic respiration rate, in terms of both the $\mathrm{C}_{\mathrm{T}}$ efflux and the $\mathrm{O}_{2}$ uptake rate, and of the benthic DOC flux, was observed at 2 of the stations (Stns KA1 and KA2). All fluxes were significantly higher in spring than in fall. (3) We did not observe any influence of the Black Sea water, which enters the Aegean Sea in the study area, on benthic respiration rates or organic carbon burial rates. (4) A significant positive correlation was found between both $\mathrm{C}_{\mathrm{T}}$ and $\mathrm{O}_{2}$ fluxes and the mean chl $a$ concentration in surficial sediments, which suggests that the benthic respiration rates, to a large extent, were controlled by the availability of labile phytodetrital organic matter in these sediments. (5) Using biomass (dry wt) as the faunal parameter, we did not observe any influence of macrofauna on either $\mathrm{C}_{\mathrm{T}}$ fluxes or oxygen uptake rates. (6) The DOC fluxes, calculated from porewater gradients and taking into account the influence of biodiffusion and bioirrigation, were generally similar to, or in the low range of, previously estimated DOC fluxes from other continental margin sediments. However, the DOC flux corresponded to $7-27 \%$ (average $14 \pm 8.1 \%$ ) of the $\mathrm{C}_{\mathrm{T}}$ flux, indicating that its contribution to the overall recycling of organic carbon in these sediments was important. (7) The organic carbon burial efficiencies (or \% organic carbon preserved) ranged from 0.1 to $5.3 \%$ (average $1.6 \pm 2.2 \%$ ). The burial efficiency at Stn KA1 (average $4 \%$ ) was considerably higher than the average for the other stations $(0.3 \%)$. The obtained burial efficiencies were, except for Stn KA1 at the southern end of the transect, very low compared to other sediments with similar accumulation rates. (8) The average burial flux of organic carbon corresponded to $0.8 \%$ of the annual mean primary production rate (PP) for the Aegean at Stn KA1, and to $0.07 \%$ of PP at the other stations. Organic carbon sequestering in sediments of the northern Aegean Sea can thus not be considered quantitatively important in the carbon cycle of this oligotrophic continental margin environment.
Acknowledgements. We thank the chief scientist E. Christou, and the captain and crew of the RV 'Aegaeo' for help and support during the 2 cruises; $\mathrm{K}$. Christodoulou for assistance and for bringing the IMBC lander on the fall 1999 cruise; M. Persson for running the alkalinity analyses; N. Simboura, M. A. Pancucci and W. Plaiti, who identified-down to species level - the benthic animals with the exception of mollusks; and 4 anonymous reviewers for constructive comments which helped improve the paper. Financial support for this study was provided by the European Commission through the EUMAST III project KEYCOP (key coastal processes in the mesotrophic Skagerrak and the oligotrophic North Aegean Sea - a comparative study) under contract number MASCT97-0148, and by the Swedish Natural Science Research Council (NFR).

\section{LITERATURE CITED}

Aller RC (1982) The effects of macrobenthos on chemical properties of marine sediment and overlying water. In: McCall PL, Tevesz MJS (eds) Animal-sediment relations, Vol 2. Plenum Press, Princeton, NJ, p 53-102

Aller RC, Aller JY (1998) The effect of biogenic irrigation intensity and solute exchange on diagenetic reaction rates in marine sediments. J Mar Res 56:905-936

Aller RC, Hall POJ, Rude PD, Aller JY (1998) Biogeochemical heterogeneity and suboxic diagenesis in hemipelagic sediments of the Panama Basin. Deep-Sea Res I 45:133-165

Alperin MJ, Martens CS, Albert DB, Suayah IB, Benninger LK, Blair NE, Jahnke RA (1999) Benthic fluxes and porewater concentration profiles of dissolved organic carbon in sediments from the North Carolina continental slope. Geochim Cosmochim Acta 63:427-448

Anderson LG, Hall POJ, Iverfeldt $\AA$, Rutgers van der Loeff MM, Sundby B, Westerlund SFG (1986) Benthic respiration measured by total carbonate production. Limnol Oceanogr 31:319-329

Archer D, Devol A (1992) Benthic oxygen fluxes on the Washington shelf and slope: a comparison of in situ microelectrode and chamber flux measurements. Limnol Oceanogr 37:614-629

Barnett PRO, Watson J, Connely D (1984) A multiple corer for taking virtually undisturbed samples from shelf, bathyal and abyssal sediments. Oceanol Acta 7:399-408

Berelson WM, McManus J, Coale KH, Johnson KS, Kilgore T, Burdige D, Pilskaln C (1996) Biogenic matter diagenesis on the sea floor: a comparison between two continental margin transects. J Mar Res 54:731-762

Berger WH, Smetacek VS, Wefer G (1989) Ocean productivity and paleoproductivity - an overview. In: Berger $\mathrm{WH}$, Smetacek VS, Wefer G (eds) Productivity of the ocean: present and past. John Wiley \& Sons, New York, NY, p 471

Berner RA (1980) Early diagenesis: a theoretical approach. Princeton University Press, Princeton, NJ

Berner RA (1982) Burial of organic carbon and pyrite sulfur in the modern ocean: its geochemical and environmental significance. Am J Sci 282:451-473

Berner RA, Canfield DE (1989) A new model for atmospheric oxygen over phanerozoic time. Am J Sci 289:333-361

Burdige DJ (2002) Sediment pore waters. In: Hansell DA, Carlson CA (eds) Biogeochemistry of marine dissolved organic matter. Academic Press, San Diego, CA, p 611-663

Burdige DJ, Homstead J (1994) Fluxes of dissolved organic carbon from Chesapeake Bay sediments. Geochim Cosmochim Acta 58:3407-3424 
Burdige DJ, Alperin MJ, Homstead J, Martens CS (1992) The role of benthic fluxes of dissolved organic carbon in oceanic and sedimentary carbon cycling. Geophys Res Lett 19:1851-1854

Burdige DJ, Berelson WM, Coale KH, McManus J, Johnson KS (1999) Fluxes of dissolved organic carbon from California continental margin sediments. Geochim Cosmochim Acta 63:1507-1515

Canfield DE (1993) Organic matter oxidation in marine sediments. In: Wollast R, Mackenzie FT, Chou L (eds) Interaction of $\mathrm{C}, \mathrm{N}, \mathrm{P}$ and biochemical cycles and global change, Vol. 14. NATO ASI Series, Springer-Verlag, Berlin, p 333-363

Canfield DE (1994) Factors influencing organic carbon preservation in marine sediments. Chem Geol 11: 315-329

Falkowski PG, Sucher J (1981) Rapid, quantitative separation of chlorophylls and their degradation products by highperformance liquid chromatography. J Chromatogr 213: 349-351

Folk RL (1954) Distinction between grain size and mineral composition in sedimentary rock nomenclature. J Geol 62: 334-359

Glud RN, Gundersen JK, Jørgensen BB, Revsbech NP, Schulz HD (1994) Diffusive and total oxygen uptake of deep-sea sediments in the eastern south Atlantic Ocean: in situ and laboratory measurements. Deep-Sea Res I 41:1767-1788

Glud RN, Holby O, Hoffmann F, Canfield DE (1998) Benthic mineralization and exchange in Arctic sediments (Svalbard, Norway). Mar Ecol Prog Ser 173:237-251

Glud RN, Gundersen JK, Holby O (1999) Benthic in situ respiration in the upwelling area off central Chile. Mar Ecol Prog Ser 186:9-18

Glud RN, Gundersen JK, Røy H, Jørgensen BB (2003) Seasonal dynamics of benthic $\mathrm{O}_{2}$ uptake in a semienclosed bay: importance of diffusion and faunal activity. Limnol Oceanogr 48:1265-1276

Goyet C, Snover AK (1993) High-accuracy measurements of total dissolved inorganic carbon in the ocean - comparison of alternate detection methods. Mar Chem 44:235-242

Hall POJ, Anderson LG, Rutgers van der Loeff MM, Sundby B, Westerlund SFG (1989) Oxygen uptake kinetics in the benthic boundary layer. Limnol Oceanogr 34:734-746

Hall POJ, Anderson LG, Holby OS, Kollberg S, Samuelson MO (1990) Chemical fluxes and mass balance in a marine fish cage farm. Mar Ecol Prog Ser 61:61-73

Haraldsson C, Anderson LG, Hassellöv M, Hulth S, Olsson K (1997) Rapid, high-precision potentiometric titration of alkalinity in ocean and sediment pore waters. Deep-Sea Res 44:2031-2044

Hartnett HE, Devol AH (2003) Role of strong oxygen-deficient zone in the preservation and degradation of organic matter: a carbon budget for the continental margins of northwest Mexico and Washington State. Geochim Cosmochim Acta 67:247-264

Henrichs SM, Reeburgh WS (1987) Anaerobic mineralization of marine sediment organic matter: Rates and the role of anaerobic processes in the oceanic carbon economy. Geomicrobiol J 5:191-237

Holcombe BL, Keil RG, Devol AH (2001) Determination of pore-water dissolved organic carbon fluxes from Mexican margin sediments. Limnol Oceanogr 46:298-302

Holland HD (1984) The chemical evoloution of the atmosphere and oceans. Princeton University Press, Princeton, NJ

Hulth S, Blackburn TH, Hall POJ (1994) Arctic sediments (Svalbard): consumption and microdistibution of oxygen. Mar Chem 46:293-316
Hulth S, Tengberg A, Landen A, Hall POJ (1997) Mineralization and burial of organic carbon in sediments of the southern Weddell Sea (Antarctica). Deep-Sea Res I 44: 955-981

Hulthe G, Hulth S, Hall POJ (1998) Effect of oxygen on degradation rate of refractory and labile organic matter in continental margin sediments. Geochim Cosmochim Acta 62:1319-1328

Ignatiades L, Psarra S, Zervakis V, Pagou K, Souvermezoglou E, Assimakopoulou G, Gotsis-Skretas O (2002) Phytoplankton size-based dynamics in the Aegean Sea (Eastern Mediterranean). J Mar Syst 36:11-28

Jahnke RA (1990) Early diagenesis and recycling of biogenic debris at the seafloor, Santa Monica Basin, California. J Mar Res 48:413-436

Jahnke RA (1996) The global ocean flux of particulate organic carbon: areal distribution and magnitude. Global Biogeochem Cycles 10:71-88

Jespersen AM, Christoffersen K (1987) Measurements of chlorophyll a from phytoplankton using ethanol as extraction solvent. Arch Hydrobiol 109:445-454

Josefson AB, Rasmussen B (2000) Nutrient retention by benthic macrofaunal biomass of Danish estuaries: importance of nutrient load and residence time. Estuar Coast Shelf Sci 50:205-216

Karageorgis AP, Kaberi HG, Tengberg A, Zervakis V, Hall POJ, Anagnostou CHL (2003) Comparison of particulate matter distribution, in relation to hydrography, in the mesotrophic Skagerrak and the oligotrophic northeastern Aegean Sea. Cont Shelf Res 23:1787-1809

Kristensen E, Blackburn TH (1987) The fate of organic carbon and nitrogen in experimental marine sediment systems of bioturbation and anoxia. J Mar Res 45:231-257

Liu KK, Atkinson L, Chen CTA, Gao S, Hall J, Macdonald RW Talaue-McManus L, Quinones R (2000a) Exploring continental margin carbon fluxes on a global scale. EOS, Trans Am Geophys Union 81:641-644

Liu KK, Iseki K, Chao SY (2000b) Continental margin carbon fluxes. In: Hanson RB, Ducklow HW, Field JG (eds) The changing ocean carbon cycle. Cambrige University Press, Cambridge, p 187-239

Lykousis V, Chronis G, Tselepides A, Price NB and 10 others (2002) Major outputs of the recent multidisciplinary biogeochemical researches undertaken in the Aegean Sea. J Mar Syst 33-34:313-334

Martens CS, Haddad RI, Chanton JP (1992) Organic matter accumulation, remineralization and burial in an anoxic coastal sediment. In: Whelan JK, Farrington JW (eds) Organic matter: productivity, accumulation and preservation in recent and ancient sediments. Columbia University Press, New York, p 82-98

Middelburg JJ, Soetaert K, Herman PMJ (1997) Empirical relationships for use in global diagenetic models. DeepSea Res I 44:327-344

Mucci A, Sundby B, Gehlen M, Arakaki T, Zhong S, Silverberg $N(2000)$ The fate of carbon in continental shelf sediments of eastern Canada: a case study. Deep-Sea Res II 47: $733-760$

Norkko A, Hewitt JE, Thrush SF, Funnell GA (2001) Benthicpelagic coupling and suspension-feeding bivalves: linking site-specific sediment flux and biodeposition to benthic community structure. Limnol Oceanogr 46:2067-2072

O'Sullivan DW, Millero FJ (1998) Continual measurement of the total inorganic carbon in surface seawater. Mar Chem 60:75-83

Pfannkuche O (1993) Benthic response to the sedimentation of particulate organic matter at the biotrans station, 47 - 
Degrees-N, 20-Degrees-W. Deep-Sea Res II 40:135-149

Rasmussen H, Jørgensen BB (1992) Microelectrode studies of seasonal oxygen uptake in a coastal sediment: role of molecular diffusion. Mar Ecol Prog Ser 81:289-303

Rutgers van der Loeff MM, Anderson LG, Hall POJ, Josefson AB, Sundby B, Westerlund SFG (1984) The asphyxiation technique: an approach to distinguishing between molecular diffusion and biologically mediated transport at the sediment-water interface. Limnol Oceanogr 29:675-686

Sakellariou D, Bakopoulou A, Anagnostou C, Roussakis G, Georgiou P, Lykousis V (2000) Holocene shelf sedimentation on Lemnos and Samothraki plateau, N.Aegean Sea. In: 6th Hellenik Symp Oceanogr Fish Proc, Vol. 1, Chios, Athens, p 231-236

Silverberg N, Sundby B, Mucci A, Zhong S, Arakaki T, Hall POJ, Landen A, Tengberg A (2000) Remineralization of organic carbon in eastern Canadian continental margin sediments. Deep-Sea Res II 47:699-731

Skoog A, Hall POJ, Hulth S, Paxéus N, Rutgers van der Loeff M, Westerlund S (1996) Early diagenetic production and sediment-water exchange of fluorescent dissolved organic matter in the coastal environment. Geochim Cosmochim Acta 60:3421-3431

Smith KL (1978) Benthic community respiration in the NW Atlantic Ocean: in situ measurements from 40 to $5200 \mathrm{~m}$. Mar Biol 47:337-347

Smith KL, Glatts RC, Baldwin RJ, Beaulieu SE, Uhlman AH, Horn RC, Reimers CE (1997) An autonomous, bottomtransecting vehicle for making long time-series measurements of sediment community oxygen consumption to abyssal depths. Limnol Oceanogr 42:1601-1612

Ståhl H, Tengberg A, Brunnegard J, Hall POJ (2004a) Recycling and burial of organic carbon in sediments of the Porcupine Abyssal Plain, NE Atlantic. Deep-Sea Res I (in press)

Editorial responsibility: Otto Kinne (Editor),

Oldendorf/Luhe, Germany
Ståhl H, Tengberg A, Brunnegard J, Bjornbom E and 7 others (2004b) Factors influencing organic carbon recycling and burial in Skagerrak sediments. J Mar Res (in press)

Strickland JD, Parsons TR (1972) A practical handbook of seawater analysis, 2nd edn. Bull Fish Res Board Can 167, Ottawa

Stuiver M (1998) Intcal. 98: radiocarbon age calibration, 24 000-0 cal. BP. Radiocarbon 40:1041-1083

Tahey TM, Duineveld GCA, Berghuis EM, Helder W (1994) Relation between sediment-water fluxes of oxygen and silicate and faunal abundance at continental shelf, slope and deep-water stations in the northwest Mediterranean. Mar Ecol Prog Ser 104:119-130

Tengberg A, Ståhl H, Gust G, Mueller V, Arning U, Andersson H, Hall POJ (2004) Intercalibration of benthic flux chambers I. Accuracy of flux measurements and influence of chamber hydrodynamics. Progr Oceanogr (in press)

Thamdrup B, Canfield DE (2000) Benthic respiration in aquatic sediments. In: Sala OE, Jackson RB, Mooney HA, Howarth RW (eds) Methods in ecosystem science. Springer-Verlag, New York, p 86-103

Tselepides A, Papadopoulou KN, Podaras D, Koutsoubas D (2000) Macrobenthic community structure of the Aegean Sea. In: 6th Hellenik Symp Oceanogr Fish, Chios, Athens, p 275-279

Wenzhöfer F, Glud RN (2002) Benthic carbon mineralization in the Atlantic: a synthesis based on in situ data from the last decade. Deep-Sea Res I 49:1255-1279

Wollast R (1991) The coastal organic carbon cycle: fluxes, sources, and sinks. In: Mantoura RFC, Martin JM, Wollast $\mathrm{R}$ (eds) Ocean margin processes in global change. John Wiley \& Sons, New York, p 365-381

Zervakis V, Georgopoulos D, Drakopoulos P (2000) The role of North Aegean in triggering the recent Eastern Mediterranean climatic changes. J Geophys Res 105:103-116

Submitted: February 17, 2003; Accepted: November 11, 2003 Proofs received from author(s): March 5, 2004 